\title{
Unravelling incoherence: utilizing property theory to challenge the classification of animals as chattels
}

\author{
Anna Wotherspoon* \\ BSc, LLB (Hons) Monash University
}

In law, domesticated animals are chattels, the object of property rights. This classification does not reflect the characteristics and capacities of nonhuman animals that make them unlike other objects of property. The categorization also fails to reflect widely held beliefs that animals deserve some moral consideration. In recognition of these difficulties, a literature has developed to advance the case for animal rights and alternative frameworks for animal protection. Yet the literature has neglected one logically antecedent issue: the normative suitability of property status itself. The property paradigm provides a straightforward legal mechanism for the exercise of control over others, as seen in its historical influence over the treatment of children and married women; yet in the animal context, its suitability has remained unscrutinized. This article does not rely on moral objections to the classification of animals as property. It focuses instead on reasons of legal theory that challenge this hegemony. Consideration of animal welfare legislation provides a preliminary indication that animals' property status is unsuitable. Regardless of whether property is conceived as the right to exclude or a 'bundle' of rights, protection of the interests of objects is inconsistent with other frameworks that regulate proprietary relations. Moreover, a comprehensive examination of traditional justifications for the private property institution reveals that animal property does not serve the purposes for which the institution was established. These analyses expose the normative incoherence of the classification of animals as chattels.

Keywords: animal protection, animal welfare law, capabilities theory, Hegel, property theory

\section{INTRODUCTION}

In the Roman legal tradition, domestic nonhuman animals are chattels, the objects of property rights. ${ }^{1}$ This classification fails to comprehend the fundamental differences that exist between animals and other chattels. Animals are sentient beings who possess, and are actuated by, preference and welfare interests. ${ }^{2}$ But as objects of property, animal

* A previous version of this article was submitted for assessment in the Honors program at Monash Law School. I am grateful to Associate Professor Patrick Emerton and Dr Joanna Kyriakakis for their insights and feedback and the anonymous reviewers for their thoughtful comments.

1. Deborah Cao, Animal Law in Australia (2nd ed, Thomson Reuters 2015) 69. Note that wild animals are not the object of absolute property; see generally at 69-83 and Part 2.1 for representative summary.

2. In this context, sentience is used to mean a capacity for perception and feeling, particularly of pleasure and pain: Donald Broome, Sentience and Animal Welfare (CABI Publishing 2014) 5; David DeGrazia, Taking Animals Seriously: Mental Life and Moral Status (Cambridge University 
interests are not recognized by the common law. ${ }^{3}$ Objects of property are the subject of a right-holder's proprietary right; they have no rights or entitlements of their own. As Gary Francione has identified, the classification of 'property' removes animal interests from the purview of legal concern and legitimizes the exploitation of animals, subject to legislative overlay. ${ }^{4}$ An owner's rights over their animal property sanction the realization of human interests (including those of the most trivial variety) and the subordination of animal interests, including the animals' most fundamental interests in avoiding pain and death. ${ }^{5}$

Many animal scholars consider property status to be the root cause behind animal exploitation. ${ }^{6}$ As recognized by Lord Erskine more than 200 years ago, '[a]nimals are considered as property only: to destroy or to abuse them, from malice to the proprietor, or with an intention injurious to his interest in them, is criminal; but the animals themselves are without protection; the law regards them not substantively'. ${ }^{7}$ Not only is this classification insensitive to animal sentience, it runs counter to intuitive beliefs we may hold about animals - a dog is fundamentally unlike a chair. ${ }^{8}$ As a result, most jurisdictions across the globe give formal recognition to animal sentience through legislative restrictions that limit what an owner may do with their animal property. These legislative regimes distinguish animals from other objects of property, but their status as property fundamentally limits the protection provided. This article seeks to move beyond the property paradigm and give meaningful legal recognition to animals' special characteristics by appealing to traditional, anodyne work on legal theory and avoiding reliance on divisive arguments based on the morality of human treatment of other animals. To do so, the article examines the nature of property rights and the legal philosophy that underpins the private property institution. It concludes that these resources identify property status as an unsuitable classification for animals in this article, used to refer to nonhuman vertebrate animals. ${ }^{9}$

Press 1995) 3. See further Philip Low, 'Cambridge Declaration of Consciousness' (Declaration, Francis Crick Memorial Conference on Consciousness in Human and Non-Human Animals, University of Cambridge, 7 July 2012). See Tom Regan, The Case for Animal Rights (2nd ed, University of California Press 2004) 87-88 regarding welfare and preference interests, and Parts 2.1 and 3.1.2 (respectively) for further discussion. See also DeGrazia (n 2) 226-331 for an analysis surrounding why the possession of interests is properly limited to sentient beings.

3. J De Montmorency, 'State Protection of Animals at Home and Abroad' (1902) 18 Law Quarterly Review 31, 31; Francione attributes the common law's erasure of animal interests to the inability of property to hold legal rights: Gary Francione, Animals, Property and the Law (Temple University Press 2004) 22.

4. Francione (n 3) 22.

5. ibid $18-19$.

6. See, for example, Francione (n 3) and Steven Wise, Rattling the Cage (Perseus Publishing 2000) ('Rattling the Cage').

7. T Hansard, The Parliamentary Debates of the Parliament of Great Britain (1818) Vol 14, 15 May 1809 , column 554.

8. As noted by Bablitch $\mathrm{J}$ in the Wisconsin Supreme Court, "we are uncomfortable with the law's cold characterization of a $\operatorname{dog} \ldots$ as mere "property". ... The term inadequately and inaccurately describes the relationship between a human and a dog': Rabideau $v$ City of Racine, 627 N.W.2d 795, 798 (Wis, 2001) (citations omitted).

9. Animals in non-vertebrate phyla are not explicitly covered by this article. However, significant research explores the intelligence of cephalopods, a class within the Mollusca phyla, and aspects of the analysis may thus be applicable to them. See Jennifer Mather and Michael Kuba, 'The Cephalopod Specialities: Complex Nervous System, Learning and Cognition' (2013) 91 Canadian Journal of Zoology 431. 
In contemporary economies, billions of animals are slaughtered each year in the name of dietary preference, science, entertainment and beauty. ${ }^{10}$ By and large, these animals live in appalling conditions on factory farms, in research facilities or in small cages as part of some other exploitative institution. These practices sit consistently within the property paradigm and have led to various attempts to formulate a protective regime for nonhuman animals. ${ }^{11}$ This article challenges the classification of animals as property in a novel way, by addressing the complex question of whether their present legal classification coheres with the seminal oeuvre on property theory. ${ }^{12}$ Grappling with questions surrounding the suitability of property status presents the possibility of a normatively persuasive perspective from which to advocate for a change to the foundational legal status of animals. The conclusion that animals are an unsuitable object of property rights advances a number of other approaches that seek to secure meaningful protection for animals.

Part 2 examines the present mechanism used to address the dissimilarities between animals and other chattels: welfare legislation. Welfare legislation is commonly regarded as a panacea that suitably addresses these differences. Yet it is a peculiar solution. Welfare legislation operates to restrict the property rights of animal owners. These restrictions are exceptional because they respond to interests that do not motivate other property restrictions: the interests of the object of property. That welfare legislation is incongruous within the great body of property restrictions does not necessarily mean it is problematic as a matter of legal theory. However, the anomaly provides a strong indication that something is amiss; namely, that animals are an unsuitable object of property rights. This suspicion is confirmed upon examination of traditional justifications for the private property institution. The examination unveils the doctrinal flaws in the classification of animals as property.

A number of theories are used to justify the private property institution. ${ }^{13}$ Part 3 classifies those theories into two categories. Two arguments address one category of justificatory theory; a final argument addresses the other. The first argument focuses upon Martha Nussbaum's capability theory of justice as a modern extension of Aristotle's work on human wellbeing. Nussbaum identifies human and nonhuman animals as necessary participants within her capability framework, in which propertyholding is a central capability. Scrutinizing Nussbaum's theory on its own terms, capability-exercising forms of life are unsuitable objects of property. Objects of property are unable to realize their capabilities in any meaningful way because they are necessarily subject to another individual's exercise of their capability to hold property. The second argument considers George Hegel's theory on private property and free will.

10. Peter Singer, Animal Liberation (4th ed, HarperCollins Publishers 2009) x-xiii.

11. See Wise, Rattling the Cage (n 6) and Regan (n 2) for personhood theories, David Favre, 'Equitable Self-Ownership for Animals' (2000) 50 Duke Law Journal 473 on equitable selfownership, and Will Kymlicka and Sue Donaldson, 'Animals and the Frontiers of Citizenship' (2014) 34(2) Oxford Journal of Legal Studies 201 on animal citizenship.

12. Alternative approaches to determining suitable legal categorizations exist: see Jennifer Nedelsky, 'Property in Potential Life - A Relational Approach to Choosing Legal Categories' (1993) 6 Canadian Journal of Law and Jurisprudence 343. Nedelsky's approach identifies appropriate legal categories by reference to the 'sorts of relationships a given category is likely to foster': at 345, and was used to reject property status as an appropriate classification in the context of products derived from new reproductive technologies.

13. See Gregory Alexander and Eduardo Peñalver, An Introduction to Property Theory (Cambridge University Press 2012). 
For Hegel, human personality develops through embodiment of the will in (privately owned) property. Embodiment of the will in property is permissible where the only 'purpose' an object can exhibit is a purpose given to it by humans or known to humans. The literature on animal autonomy suggests that animals can imbue themselves with purpose by acting upon their own perceptions, expectations and preferences in a manner that is not amenable to human knowledge. The result is that animals are an impermissible object for the embodiment of human will, so do not serve the purpose of the private property institution. These ideas are also extended to Immanuel Kant's theory of property.

The final argument addresses those theories that justify private property on the basis that it maximizes society's available and productive resources. Private control over assets places certain constraints on the workings of property rules and the demands they impose on objects of property. One of these demands is that objects possess the quality of stability in a spatial and temporal sense. Stability allows the subject matter of the right to be assigned to, and controlled by, someone. In the animal context, stability is imposed through confinement. Yet modern regimes of animal confinement cause the deterioration of valuable resources. This undermines the public good that private property serves. Under each justificatory theory, animals bring normative incoherence to the private property institution and emerge as an unsuitable or ill-fitting object of property. Part 4 considers the consequences of this conclusion for the legal classification of animals. Part 5 concludes.

\section{ANIMAL PROPERTY}

\subsection{The Purpose of Welfare Legislation}

Animals are unique objects of property. Their singularity within the world of objects is attributable to their self-actuating behavior and sentience. Beyond representing points of dissimilarity between animals and, for example, chairs, these characteristics cause some tension for the property status of animals and have led to the development of animal welfare protections. At a basic level, welfare (or 'anti-cruelty') legislation operates to impose restrictions upon an owner's property rights with respect to their animal property. ${ }^{14}$ These restrictions recognize that certain property rights (at least when unregulated) are not suitable in their application to animals. ${ }^{15}$ In the absence of welfare legislation, an animal owner has the absolute right to control and exploit their animal, and waste, harm, neglect or destroy it. ${ }^{16}$ Welfare legislation limits these property rights in response to animal interests by seeking to protect those interests. This statement is not without controversy and is explored in the remainder of this section.

The common law draws a distinction between the legal classification of domesticated and wild animals. ${ }^{17}$ Domestic animals are those 'commonly kept and cared for

14. Note that certain welfare restrictions also extend to wild animals.

15. Cao (n 1) 48 .

16. The use of the pronoun 'it' to describe sentient individuals is problematic and further reinforces animals' status as property. This article provides arguments that dismantle the property classification and so alternative language (for example, 'he', 'her', 'them') would be preferable. Nonetheless, the author uses the pronoun 'it' for reasons of linguistic convention.

17. Cao (n 1) 78; this is a question of law, not fact. 
in and about human habitations' and are the subject of absolute property. ${ }^{18}$ Wild animals in their natural state are not objects of property. ${ }^{19}$ They are, however, the object of qualified property rights when brought under human control. ${ }^{20}$ Prior to the adoption of anti-cruelty statutes, animals were protected through the statutory prohibitions of malicious mischief and trespass. ${ }^{21}$ These laws offered 'pure property' protection for animals $;{ }^{22}$ animals were protected because they were the personal property of some person. In contrast, welfare legislation purports to protect animals regardless of their status as property.

The shift from malicious mischief to anti-cruelty statutes was recognized, even in early judicial statements, to disclose a change of purpose from punishment of property offences to prevention of animal cruelty. ${ }^{23}$ This change was borne of an appreciation of animals' capacity to suffer. The eighteenth century saw a shift away from Descartes' notion of animals as machines and towards an understanding of animals as thinking and feeling individuals that possess independent interests. ${ }^{24}$ Cruelty to animals 'had gained new visibility' and was 'so blatant that everyday new people were falling into sympathy with the animal protection cause'. ${ }^{25}$ To recall the famous words of Jeremy Bentham in his critical commentary of Blackstone's work, 'the question is not can they reason, nor can they talk, but can they suffer?'26

The Cruel Treatment of Cattle Act 1822 ('Martin's Act') is generally recognized as the first statute that specifically targeted animal cruelty. ${ }^{27}$ Richard Martin and Lord Erskine were integral to its passage and the introduction of earlier legislation that failed to pass. Historical records indicate that these individuals hoped to act on behalf of animals and give animals protection 'in themselves' ${ }^{28}$ Martin's Act protected cattle, horses, mules and sheep from wanton and cruel beating, abuse and ill-treatment by providing a mechanism for private enforcement and giving the court power to impose fines and imprisonment. ${ }^{29}$ The Society for the Prevention of Cruelty to Animals was formed in 1824 to carry out the task of investigating and prosecuting cruelty. Martin's Act was quickly followed by the Cruelty to Animals Act 1835, which extended

18. Attorney-General (SA) v Bray (1964) 111 CLR 402, 425; LexisNexis, Halsbury's Laws of Australia (online at 20 September 2019) 20 Animals, '1 Legal Status of Animals' [20-10]; Saltoon v Lake [1978] 1 NSWLR 52.

19. Cao (n 1) 79 .

20. Note that these rights do not subsist when the animal escapes control: ibid.

21. Francione (n 3) 121.

22. ibid.

23. Horton v State, 27 So. 468 (Ala. 1900) 468.

24. Kathryn Shevelow, For the Love of Animals: The Rise of the Animal Protection Movement (Henry Holt and Company 2008) 150.

25. ibid 251 .

26. Jeremy Bentham, An Introduction to the Principles of Morals and Legislation (Clarendon Press 1789, 2nd ed 1823, 1907 reprint) 310.

27. Cruel Treatment of Cattle Act 1822 (3 George 4 c. 71); Jerry Anderson, 'The Origins and Efficacy of Private Enforcement of Animal Cruelty Law in Britain' (2012) 17 Drake Journal of Agricultural Law 263, 263-64. Nonetheless, earlier legislation does appear on record; namely, the Act against Plowing by the Tayle, and Pulling the Wooll off Living Sheep (1635) (Ireland). 28. See generally Shevelow (n 24) chapters 8-13, and particularly at 235, where Lord Erskine's failed bill of 1809 is described as 'in a real sense ... the first actual animal protection legislation, the first whose stated aim was to give animals protection in themselves from "wilful and wanton cruelty"'.

29. Cruel Treatment of Cattle Act 1822 (3 George 4 c.71). 
protection by prohibiting dogfighting, cockfighting and the keeping of premises for baiting certain animals. ${ }^{30}$ The 1835 Act also required keepers of confined animals to provide adequate nourishment and included certain 'self-help' enforcement provisions. $^{31}$

When first enacted, welfare legislation sought to provide limited protection to a small number of animals. The legislation was directed towards economically valuable livestock animals such as horses and cattle. ${ }^{32}$ Modern legislation extends protection to a much more comprehensive list of animal species. For example, the Victorian Prevention of Cruelty to Animals Act 1986 ('POCTA') defines 'animal' to include, inter alia, 'a live member of the vertebrate species'. ${ }^{33}$ The operative provisions of welfare legislation have become more demanding as the legislation has evolved. Early Acts prohibited only the malicious killing, maiming or wounding, or malicious and cruel beating or torture of commercially valuable animals. ${ }^{34}$ Later statutes imposed criminal liability for both negligent and intentional acts, without reference to the term 'malicious'. ${ }^{35}$ The types of prohibited conduct gradually enlarged. ${ }^{36}$ Eventually welfare legislation began to impose positive duties upon owners to provide shelter and feed for their animal. ${ }^{37}$ The Victorian POCTA exemplifies the more expansive formulations of modern laws. A person must not wound, overwork or terrify an animal, or subject it to unreasonable pain and suffering. ${ }^{38}$ Owners or persons in charge of an animal have positive duties to ensure their animal has sufficient food, water and shelter, and receives veterinary or other appropriate treatment if sick or injured. ${ }^{39}$ These developments clearly reveal a growing social concern to protect animal interests because animals are capable of suffering, and not on the basis that those animals are mere property that holds value to humans. ${ }^{40}$ The question then arises as to why the prevention of animal suffering was (and is) sought. This issue is more contentious.

The legislators who introduced anti-cruelty legislation in Britain were motivated by concern for the plight of animals and sought protection for the animals' own benefit. ${ }^{41}$ After a number of unsuccessful attempts to pass the legislation, modern historians have plausibly suggested that the public's new awareness of animal suffering was an important contributing factor to the eventual passage of Martin's Act. ${ }^{42}$ Early welfare legislation is commonly understood to have arisen in response to the visible and pervasive cruelty inflicted upon working animals in the streets of London,

30. Cruelty to Animals Act 1835 (5 \& 6 Will. 4, c. 59).

31. ibid ss $2-5,13,17$.

32. See generally David Favre and Vivien Tsang, 'The Development of Anti-Cruelty Laws During the 1800's' (1993) 1993(1) Detroit College of Law Review 1, and particularly at 8.

33. Prevention of Cruelty to Animals Act 1986 (Vic) s 3 ('POCTA').

34. See Favre and Tsang (n 32) 9 and their discussion of the New York Statute of 1829.

35. ibid $14-16$.

36. ibid 14.

37. For a more comprehensive summary of the development of American anti-cruelty law, see Favre and Tsang (n 32). For a comprehensive overview of nineteenth century British animal welfare legislation, see Shevelow (n 24).

38. POCTA (n 33) s 9.

39. ibid.

40. Favre and Tsang (n 32) 2; Maneesha Deckha, 'Welfarist and Imperial: The Contributions of Anticruelty Laws to Civilizational Discourse' (2013) 65(3) American Quarterly 515, 517.

41. See Shevelow (n 24) chapters 11-13, and particularly at 235 .

42. ibid 251. 
at a time when British society was developing a more general opposition to violence. ${ }^{43}$ But the statutes were also motivated by anthropocentric interests. Welfare laws were expected to elevate public morals and improve human character through reducing acts of individual violence and fostering the development of human sensibilities. $^{44}$ As noted by the Massachusetts Supreme Court in 1931, legislation that prohibited the cruel trapping of animals was directed against acts which 'have a tendency to dull humanitarian feelings and to corrupt the morals of those who observe or have knowledge of those acts'. ${ }^{45}$ Anti-cruelty laws were also understood to impose social order and control. ${ }^{46}$

The development of anti-cruelty legislation sketched above suggests the legislation has aimed to secure a number of social purposes throughout its history. Nonetheless, even original welfare legislation implicitly recognized that animals possess independent interests that leave them vulnerable to suffering, and regulated human behavior in an attempt to address that suffering. The central importance of animal suffering to the operation of anti-cruelty legislation is demonstrated by the early case of State $v$ Neal. ${ }^{47}$ A prosecution for cruelty to sea turtles was dismissed because the court 'did not believe that sea turtles could feel pain or suffering from lack of food and water' ${ }^{48}$ The court dismissed the action on the basis that the turtles could not suffer. ${ }^{49}$

The foregoing makes clear that the genesis of anti-cruelty legislation was public recognition of animal suffering. The legislation seeks to proscribe such suffering because animal cruelty is damaging either to public morals or the animals themselves. Yet some scholars assert that welfare legislation aims to secure the protection of public morals and not the protection of animals. Francione, whose work has been influential in this area, recognizes that reported cases articulate the purpose of anti-cruelty legislation as both the protection of animals and conservation of public morals. ${ }^{50} \mathrm{He}$ nonetheless identifies the former purpose as secondary to the latter. This conclusion results from the 'humanocentric focus' of welfare laws. ${ }^{51}$ The statutes 'effectively exclude from the[ir] scope of coverage ... every act of cruelty that occurs as part of industrialised animal exploitation'.52 Because anti-cruelty laws are ineffective in

43. Cao (n 1) 48-49; Anderson (n 27) 272.

44. Francione (n 3) 121-24; Favre and Tsang (n 32) 11; Anderson (n 27) 274-75. See also Anna Feuerstein, The Political Lives of Victorian Animals (Cambridge University Press 2019), and particularly chapter 4, which explores the purpose of welfare legislation as 'less [about] protection of property and more about educating citizens and helping them progress toward what was understood as a more civilised state of being': at 16 .

45. Commonwealth v Higgins, 178 N.E. 536 (Mass. 1931) 538.

46. Anderson (n 27) 273-74; Shevelow (n 24) 219; indeed, Deckha asserts that welfare legislation continues to civilize populations along race, religion, class and gender lines through targeting minoritarian practices and immunizing majoritarian ones: see generally Deckha (n 40).

47. 27 S.E. 81 (N.C. 1897).

48. Favre and Tsang (n 32) 25.

49. ibid.

50. Francione (n 3) 123. The idea that animal protection preserves public morals fundamentally derives from Kant's argument that humans owe indirect duties to animals. In his Lectures on Ethics, Kant says '[a]nimal nature has analogies to human nature, and by doing our duties to animals in respect of manifestations which correspond to manifestations of human nature, we indirectly do our duty towards humanity': Immanuel Kant, Lectures on Ethics, [tr. L. Infield] (Harper Torchbooks 1963) 239-40.

51. Francione (n 3) 124.

52. ibid 129. 
preventing animal suffering, the protection of animals cannot be a primary purpose of the legislation. Francione concludes that 'questions of animal protection really have little, if anything, to do with animal protection and everything to do with issues of human character'. 53

Francione's critique of the effectiveness of welfare laws is compelling and accurate. His selective articulation of the purpose of welfare legislation is based on mens rea requirements, statutory exclusions, judicial interpretations of 'unnecessary' and 'unjustified' cruelty and enforcement difficulties. ${ }^{54}$ These statutory devices have the result that welfare legislation does not protect the vast majority of animals from cruel conduct because institutionalized animal exploitation is infrequently caught by their provisions. ${ }^{55}$ Nevertheless, Francione's analysis sits uncomfortably with the contemporary purposive approach to statutory interpretation. A purposive approach requires that statutory provisions be given the meaning the legislature intended them to have. ${ }^{56}$ The Victorian POCTA explicitly aims to prevent cruelty to animals. ${ }^{57}$ Proposals to give explicit recognition to animal sentience in an amended purposes provision are presently under consideration. ${ }^{58}$ The purpose section of anticruelty legislation in the Australian Capital Territory explicitly recognizes that animals are 'sentient beings that are able to subjectively feel and perceive the world around them' and that possess 'intrinsic value'. ${ }^{59}$

Francione's analysis of the purpose of anti-cruelty legislation attempts to discern its ultimate purpose. This debate somewhat misses the point of the claim made in this section that anti-cruelty legislation attempts to protect the interests of animals. The shift from malicious mischief statutes to welfare legislation demonstrates legal recognition of animal interests and their resulting capacity for pain and suffering. Insofar as this article makes only the claim that welfare legislation recognizes and seeks to protect animal interests, it is unnecessary to determine whether the ultimate purpose of welfare legislation is the protection of animals through the protection of animal interests or the protection of people through the protection of animal interests. Both purposes proffered as the ultimate goal of welfare legislation require, in an immediate sense, statutory provisions that protect animal interests. Where the ultimate purpose of welfare legislation is understood as the protection of animals (as indicated by the purposes section of the Animal Welfare Act 1992 (ACT)), welfare legislation seeks to protect animal interests because animals have intrinsic value. Where the ultimate purpose of welfare legislation is understood as the protection of persons

53. ibid $125,129$.

54. ibid 135-58.

55. ibid 129; see generally chapter 7 .

56. Project Blue Sky Inc v Australian Broadcasting Authority (1998) 194 CLR 355, 384; Acts Interpretation Act 1901 (Cth) s 15AA.

57. See POCTA (n 33) s 3.

58. See Victorian Government, Department of Jobs, Precincts and Regions, A New Animal Welfare Act for Victoria (Directions Paper, October 2020) 11.

59. Animal Welfare Act 1992 (ACT) s 4A. Similarly, the title paragraph to the New Zealand Animal Welfare Act 1999 (NZ) identifies the Act as one to 'recognise that animals are sentient'. In the European context, the Treaty of Lisbon amends the Treaty of the Functioning of the European Union and instructs Member States, in formulating and implementing relevant policies, to 'pay full regard to the welfare requirements of animals', 'since animals are sentient beings': Treaty of Lisbon Amending the Treaty on European Union and the Treaty Establishing the European Community, signed 13 December 2007, 2007/C 306/01 (entered into force 1 December 2009) art 13. 
(as indicated by their ineffectiveness in protecting animals from cruelty), welfare legislation seeks to protect animal interests because public morals are corrupted when individuals with interests are subjected to cruel treatment. As even Francione has recognized, anti-cruelty legislation imposes a direct duty to treat animals humanely. ${ }^{60}$ That this protection is rendered ineffective through statutory formulations and exclusions, inadequate enforcement and judicial interpretations of 'welfare words' does not change the fact that anti-cruelty legislation attempts to protect animal interests; the interests of 'objects'. Even if one concludes that the protections provided by welfare laws are so deficient that the legislation does not seek to protect animal interests, the legislation nonetheless recognizes and responds to animal interests through providing superficial protection.

Recognizing that welfare statutes seek to protect animal interests differentiates the protection of animal objects from the protection of other objects of property (for example, cultural property) that lack independent interests and whose protection is sought purely on account of human benefit. The orientation of welfare legislation towards animal interests is clearly revealed when one notes that welfare legislation does not protect animals from humane killing or destruction. Rather, it (attempts to) protect animals from suffering through acts of cruelty. Such a distinction breaks down when applied to all other objects of property because it is meaningless to talk of the prevention of suffering vis-a-vis objects that have no interests.

This discussion has not sought to defend welfare legislation nor suggest that it provides a protective regime for animals. Instead, the discussion substantiates the claim that welfare legislation recognizes and seeks to protect the interests of animals in avoiding cruel treatment. Regardless of whether welfare legislation aims to protect animal interests for animals, or protect animal interests for people, the immediate purpose is the same: the protection of animal interests.

\subsection{Welfare Legislation: An Unusual 'Solution'}

The above discussion has defended the view that anti-cruelty statutes recognize that animals have interests and seek to protect those interests. Such protection entails restriction of the property rights of animal owners. While the reality of restriction is typical of property law, the type of restriction imposed by welfare restrictions is exceptional because welfare restrictions respond to the interests of the object of property.

The interaction between property status and welfare restrictions produces an unusual result. Animals are classified no differently from other objects of personal property, a classification that strips animals of legal value and standing. To address the issues that arise from this classification, restrictions are placed upon owners' property rights with respect to their animals. These restrictions seek (but fail to achieve) a goal that does not motivate property restrictions in any other context: the protection of the interests of objects. The resulting state of affairs is far from satisfactory: welfare legislation, the putative solution to the problem that animals are unlike other chattels, does not conform to the usual characteristics of restrictions placed upon fundamental common law property rights. Namely, and somewhat bizarrely, welfare restrictions recognize and seek to protect the interests of the object of property itself; interests that are formally erased by their legal classification. Even if one concludes that

60. Francione (n 3) 123. 
anti-cruelty statutes do not seek to protect animal interests, the legislation at least recognizes and is responsive to interests that are erased by the classification of property. The resulting incoherence provides a strong indication that something is amiss. ${ }^{61}$ To appreciate the significance of property status and restrictions directed towards animal interests, the next section summarizes the nature of property and the logic of restrictions placed upon property rights.

\subsection{The Nature of Property Rights and Restrictions}

The idea of property is a difficult one. To the layperson, the thing, resource or asset is property. But to the lawyer and legal theorist, property refers to the legal relations that exist between persons with respect to a thing. ${ }^{62}$ These relations, or property rights, exist in rem. They obtain with respect to, and are enforceable against, persons generally. ${ }^{63} \mathrm{~A}$ 'quality of relativity' pervades proprietary relations and is responsible for their 'elusive', illusionary nature. ${ }^{64}$ Nevertheless, at a high level of generality the content of property rights broadly conforms to two theoretical understandings of property. ${ }^{65}$ The exclusion theory conceives, as the defining feature of property, an owner's right to exclude non-owners from owned resources. ${ }^{66}$ Under the 'bundle of rights' model, the right to exclude is one of a number of different legal relations which together constitute ownership. ${ }^{67}$ Both theories accommodate the typical legal relations that exist between property owners and others: the right to possess, manage and use the resource for a wide range of purposes and control access by others, the right to

61. A question may be raised concerning whether incoherence in law is problematic. As noted by Cass Sunstein et al, incoherence persists in 'many domains of the law': 'Is Incoherence Outrageous?' (2002) 54 Stanford Law Review 1293 at 1293. The authors suggest that 'incoherence is indeed a problem', but note that it is not a 'trumping value': at 1300-01.

62. Hocking $v$ Director-General of the National Archives of Australia [2020] HCA 19 [202] ('Hocking'); Jeremy Waldron, The Right to Private Property (Oxford University Press 1988) 27; William Swadling, 'Property: General Principles' in Peter Birks (ed), English Private Law (Oxford University Press 2000) 204, 204.

63. Wesley Hohfeld, 'Fundamental Legal Conceptions as Applied in Judicial Reasoning' (1916) 26 Yale Law Journal 710, 719. See also Swadling (n 62) 205, who adds to the in rem nature of property the characteristic that property rights are capable of assignment to third parties.

64. Hocking (n 62) [90]; Yanner v Eaton (1999) 201 CLR 351 [17]; Kevin Gray, 'Property in Thin Air' (1991) 50 Cambridge Law Journal 252.

65. For application in a contemporary context, see Hocking (n 62) at [203]-[205].

66. Exclusion theories can be traced to Blackstone's legal commentaries, where property was famously described as 'sole and despotic dominion in total exclusion of the rights of others': William Blackstone, Commentaries on the Law of England in Four Books (JB Lippincott Co 1893) volume 1 , book 2,2 . Under exclusion theories, property rights are generally given shape by the duty imposed on non-owners to exclude themselves from objects owned by others: Simon Douglas and Ben McFarlane, 'Defining Property Rights' in James Penner and Henry Smith (eds), Philosophical Foundations of Property Law (Oxford University Press 2013) 219, 220.

67. The bundle of rights analysis has its origins in the work of Wesley Hohfeld. Hohfeld classified legal relations into the correlative categories of claim-right and duty, privilege and noright, power and liability, and immunity and disability. This framework of jural relations allows property to be broken down into precise and basic legal relations: a claim-right to exclude others, a privilege to use resources for whatever purpose, a power to alienate the resource etc: Wesley Hohfeld, 'Some Fundamental Legal Conceptions as Applied in Judicial Reasoning' 
capital and income that flows from the resource, the right to alienate the resource, the right to security (viz. an immunity from expropriation). ${ }^{68}$ For bundle theorists, each relation is a distinct right, privilege, power or liability, but for exclusion theorists, the relations are all incidents of the right to exclude.

Therefore, at the technical level, animals themselves are not property; they are the 'objects' to which certain rights attach. These rights are not enforceable or held against the animal owned; instead, they are enforceable against other persons. The animal as an individual with interests is erased by their classification. The owner's right to exclude others from their animal translates to a duty on the part of other persons to avoid interference with the animal; their 'right' (strictly, a privilege) to use the animal corresponds to a 'no-right' held by others that the owner not use their animal in any particular way. Similarly, the owner's privilege or freedom to destroy their property corresponds to other persons' 'no-right' that the owner not destroy their animal. ${ }^{69}$ Unregulated exercise of these rights does not conform with societal expectations concerning the treatment of animals. Welfare restrictions step in to mitigate these problems by purporting to give animal interests legal value.

An analysis of property restrictions need not draw a distinction between the two theories of property. Exclusion plays a fundamental role in both theories, ${ }^{70}$ empowering owners with the (liberty) right to decide how their resources will be used. ${ }^{71}$ Even for exclusion theorists, the right of exclusion is not absolute. ${ }^{72}$ Nevertheless, exclusion and bundle theories conceptualize limitations upon property rights in different ways. Applying the exclusion framework, limitations are understood as first-order constraints: general restraints on harmful action that property rules take as given. ${ }^{73}$ Owners exercise their right of exclusive use within the pre-determined framework of the laws of crime, tort etc. ${ }^{74}$ Second-order constraints correspond to the bundle theory, where prohibitions on harmful use are conceptualized as part of the standard incidents of ownership. ${ }^{75}$ On both accounts, property restrictions operate through legal

(1913) 23 Yale Law Journal 16, 30-58 ('Some Fundamental Legal Conceptions'); Waldron (n 62) 27-28; AM Honoré, 'Ownership' in AG Guest (ed), Oxford Essays in Jurisprudence (Oxford University Press 1961) 107.

68. See further Honoré (n 67) 112-24 for other standard incidents of ownership.

69. These statements utilize Hohfeld's analysis of jural relations: see Hohfeld, 'Some Fundamental Legal Conceptions' (n 67), particularly at 32-35.

70. Honoré describes 'the right to possess, viz. to have exclusive physical control of a thing ... [as] the foundation on which the whole superstructure of ownership rests': (n 67) 113. Indeed, through the exclusion of others, exclusion theory affords owners an 'open-ended set of use privileges' in relation to owned things: Douglas and McFarlane (n 66) 220, quoting JW Harris, Property and Justice (Oxford University Press 1996) 30, 45.

71. Rights of exclusion and use are 'opposite sides of the same coin': James Penner, The Idea of Property in Law (Oxford University Press 1997) 71.

72. See Waldron (n 62) 27. The idea that property is fundamentally a right of exclusive control, yet simultaneously one that is subject to restrictions (and notably, restrictions that have varied in their effect throughout history), plays out in Nedelsky's analysis of the political and legal history of United States federalism and critiques of her work. See Jennifer Nedelsky, Private Property and the Limits of American Constitutionalism: The Madisonian Framework and Its Legacy (University of Chicago Press 1909) and William Fisher III, 'Making Sense of Madison: Nedelsky on Private Property' (1993) 18 Law and Social Inquiry 547.

73. Waldron (n 62) 32; Swadling (n 62) 204.

74. Swadling (n 62) 204.

75. Honoré (n 67) 123. Nothing much turns on this distinction: Waldron (n 62) 32. 
relations between persons and are imposed to protect their interests. ${ }^{76}$ Objects cannot participate in these jural relations, as, for example, recognized by the New York Supreme Court's finding that animals cannot bear duties. ${ }^{77}$ The orientation of welfare restrictions towards animal interests reveals their exceptional nature.

\subsection{Planning Is Not an Exceptional Restriction}

There are other types of property restrictions that appear responsive to animal interests; namely, planning and environment law. Like welfare legislation, these laws interfere with owners' rights of exclusion and use by limiting what a person may do with their property. ${ }^{78}$ Some of these limitations appear to incorporate animal interests through the regulation of land use to protect biodiversity. However, a distinction should be drawn between the protection of animal interests and environmental protection, that indirectly safeguards the interests of (certain) animals. Where this distinction is drawn, the limitations imposed by welfare restrictions remain an anomaly because they respond to the interests of individual 'objects': animals.

Planning legislation protects the environment through restrictions that pertain to habitats, populations and, for highly endangered species, the individuals themselves. For example, Victorian planning schemes make reference to animals in the context of biodiversity and conservation provisions. ${ }^{79}$ Planning should 'protect the health of ecological systems and the biodiversity they support', ${ }^{80}$ and in certain zones, landscaping should be implemented to enhance 'habitat for plants and animals in locations of habitat importance' ${ }^{81}$ The provisions seek protection of rare and threatened animal and plant species and communities. ${ }^{82}$

Globally, the Convention on Biological Diversity (' $C B D$ ') operates as a framework for environmental law in 196 nation states. The Convention requires development of 'national strategies, plans or programmes for the conservation and sustainable use of biodiversity' ${ }^{83}$ Some of these strategies translate to restrictions on what states and private individuals may do with their (real) property. In Australia, legislative

76. See, for example, Bates' discussion of the common law approach to environmental protection. Historically, an owner was empowered to deal with their property in any way they chose. However, where a property owner's activities with respect to their property (particularly land) affected a neighbor's use and enjoyment of their own property, the common law would intervene to protect the neighbor's property rights: Gerry Bates, Environmental Law in Australia (9th ed, LexisNexis Butterworths 2016) 68.

77. The People of the State of New York ex rel. the Nonhuman Rights Project Inc, on behalf of Tommy v Lavery, 124 A.D. 3d 148, 153 (NY, 2014).

78. Bates (n 76) 76. 'Rights' is here used in a broad sense to include Hohfeldian claim-rights and privileges.

79. This article uses the Victoria Planning Provisions ('VPPs') to provide a general example of planning schemes. The VPPs contain a comprehensive set of planning provisions that councils across Victoria use to construct planning schemes: Department of Environment, Land, Water and Planning ('DELWP'), Victoria Planning Provisions (online at 16 July 2019) 43-46. It is an offence to use or develop land in contravention of a planning scheme: Planning and Environment Act (1987) (Vic) s 126(1).

80. DELWP (n 79) 42.

81. ibid 706.

82. For further references to biodiversity, see ibid 44, 353 and 799.

83. Convention on Biological Diversity, opened for signature 5 June 1992, 1760 UNTS 79 (entered into force 11 September 2003) art 6 ('CBD'). 
implementation of the $C B D$ is achieved through the Environment Protection and Biodiversity Conservation Act 1999 (Cth) ('EPBC Act') ${ }^{84}$ The Act generally prohibits environmentally harmful activities and creates an administrative scheme for the issue of licenses to authorize those activities on certain conditions. ${ }^{85}$ Relevant purposes of the Act are to provide for the protection of the environment, to promote ecologically sustainable development and to promote the conservation of biodiversity. ${ }^{86}$ To realize these objectives, the Act protects only those animals that hold significance from a conservation perspective. ${ }^{87}$ For example, activities that have 'significant impact' on listed threatened species or communities or listed migratory species are prohibited without approval, ${ }^{88}$ and the killing or injuring of these species without a permit is an offence ${ }^{89}$ Cetaceans and listed marine species are also protected through equivalent provisions. ${ }^{90}$ These provisions apply to individual animals, but are designed to secure conservation outcomes and protect biodiversity.

Approaches to valuing biodiversity are complex and controversial, obscuring clear identification of the interests served by attempts to protect and preserve it. ${ }^{91}$ Biodiversity or 'biological diversity' refers to the variability among living organisms from all sources and includes diversity 'within species, between species and of ecosystems'. ${ }^{92}$ Its value can broadly be characterized as anthropocentric (instrumental) and/or ecocentric (intrinsic). ${ }^{93}$ Anthropocentric understandings of biodiversity focus on the benefits biodiverse ecosystems provide for human society. ${ }^{94}$ Cetaceans, for example,

84. See Environment Protection and Biodiversity Conservation Act 1999 (Cth) s 171(4) ('EPBC Act') and Environment Australia, Australia's Second National Report to the Convention on Biological Diversity (Submission, 21 May 2001).

85. For commentary on the EPBC Act, see Bates (n 76) 223. Note that some parts of the Act are straightforwardly anti-cruelty provisions, for example ss $303 \mathrm{GO}$ and $303 \mathrm{GP}$. They create the same anomaly as discussed with relation to welfare legislation.

86. EPBC Act (n 84) s 3.

87. Note that the EPBC Act has been criticized for its selective focus on biodiversity that is formally listed as threatened: Commonwealth of Australia, Independent Review of the Environment Protection and Biodiversity Conservation Act 1999 (Interim Report, 29 June 2009) 13.

88. EPBC Act (n 84) ss 18, 18A, 20 and 20A.

89. ibid ss 196, 201, 211 and 212. Listed migratory species are those species specified in certain international agreements designed to conserve migratory birds: Australian Government, 'Listed Migratory Species', What is Protected? (Factsheet, undated) <www.environment.gov. au/epbc/what-is-protected/migratory-species $>$.

90. EPBC Act (n 84) ss 229 and 254. The initial listed marine species are specified in s 248 , and further species may only be added to secure the species' long-term conservation needs: at s 250 . Protection of cetaceans is required under the International Convention for the Regulation of Whaling, opened for signature 2 December 1946, UNTS 74 (entered into force 10 November 1948). 91. Nathalie Seddon et al, 'Biodiversity in the Anthropocene: Prospects and Policy' (2016) 283 Proceedings of the Royal Society B, Biological Sciences 2.

92. $C B D$ (n 83) art 2. See also ibid.

93. Chelsea Batavia and Michael Paul Nelson, 'For Goodness Sake! What is Intrinsic Value and Why Should We Care?' (2017) 209 Biological Conservation 366, 367. Note that theories that describe biodiversity (diversity of ecosystems and species) as possessing intrinsic value are one type of intrinsic value theory, described as 'ecocentric'. Other intrinsic value theories are biocentric, claiming that life itself is the criterion for intrinsic value, or zoocentric, claiming that individual animals possess intrinsic value: at 369. Planning and environment laws aim to protect biodiversity, so this article is concerned with ecocentric intrinsic theories.

94. This value can be conceptualized in terms of use and non-use value. Ecosystems produce food, fiber and water, ensure atmospheric maintenance and climate stability and provide 
protected under the $E P B C$ Act, were originally the subject of international regulation to encourage population recovery and enable commercial whaling to continue. ${ }^{95}$ Ecocentric understandings of biodiversity view ecosystems or species as intrinsically valuable. ${ }^{96}$ Intrinsic value cannot be reduced to economic value, ${ }^{97}$ and perhaps for this reason appeals to the intrinsic value of biodiversity do not dominate discussions surrounding biodiversity conservation. ${ }^{98}$ Ecocentric accounts do not value biodiversity for its use to humans; nor do they recognize the interests of individual animals. Rather, the interests of certain animals are incidentally protected because they are constituent parts of an intrinsically valuable ecosystem. ${ }^{99}$

Analysis of the interests that motivate planning and environment law does not disturb the exceptionalism of welfare restrictions. This conclusion creates internal tension for the legal framework surrounding animals. Through the classification of property, animals and animal interests are stripped of legal value and standing. Yet in recognition of animal interests and the wrong of animal cruelty, legislative restrictions upon property rights with respect to animals have been created to recognize and protect those interests. These restrictions are a sui generis constraint on property rights and an anomalous limitation on the fundamental right of exclusion. This internal tension is not determinative of the suitability of an animal property form. Nevertheless, it provides a strong preliminary indication of unsuitability and foreshadows greater problems of legal theory surrounding the classification of animals as property.

\section{ANIMALS AND THE JUSTIFICATIONS FOR PRIVATE PROPERTY}

Through their classification as objects of property, animals are brought within the well-established institution of private property: a system that governs access to, and control of, scarce material resources. ${ }^{100}$ For centuries, philosophers and theorists have sought to develop justifications for the institution. These justifications should not be undermined by the animal property form. The remainder of the article addresses these very issues: do the justifications for private property justify animals as an object of property rights, and if not, do animals as chattels undermine these justifications? These issues are complex. They will be dealt with by categorizing property theories into two groups, providing a brief explanation of the theories and

ecosystem services and economic benefits to society. The non-use value of ecosystems encompasses humans' aesthetic appreciation of diverse ecosystems, 'existence value' and 'bequest value': Osvaldo Salsa, '(Almost) All About Biodiversity' (2003) 299 Science 1521, 1521; Seddon et al (n 91) 2.

95. Australian Government, 'International Whaling Commission', Global protection of whales (Factsheet, undated) <www.environment.gov.au/marine/marine-species/cetaceans/ international>.

96. Batavia and Nelson (n 93) 369.

97. Seddon et al (n 91) 2.

98. The treatment of biodiversity in leading scientific journals such as Nature and Science tends to present the value of biodiversity in terms of its value to humanity: see, for example, Bradley Cardinale et al, 'Biodiversity Loss and its Impact on Humanity' (2012) 486 Nature 59; Salsa (n 94); Seddon et al (n 91).

99. Cao (n 1) 242; Donald Maier, What's So Good about Biodiversity? A Call for Better Reasoning About Nature's Value (Springer 2012) 159.

100. Swadling (n 62) 204. 
considering their application to animals. The theories do not justify an animal property form because animal property does not achieve the goods that justify the private property system.

As recognized by John Rawls, an institution's overarching goal or purpose is often independent of the rules that govern the institution. ${ }^{101}$ Frequently, drawing a distinction between the justifications for an institution and the justifications for actions taken within it will best serve the institution's overarching goal. Considering the property institution, an owner's use and management of their resources, and the permissible limitations that restrict that use, are determined by constitutive and regulative property rules that largely translate to the legal relations explored in Part 2. But the justifications for these rules are best conceived as independent of the justifications for the property institution itself. The determination of which particular rules will realize the institution's overarching goal requires the making of future-focused, prospective judgments: what are the outcomes a particular action will bring about, and do they serve the overarching goal? These judgments are complex and individualized, and provide good reason to conclude that a system governed by practical and workable bright-line rules will better achieve the institutional goal. ${ }^{102}$ This article now turns to a consideration of the overarching goals of the property institution, viz. the justifications for implementing the particular property rules and relations discussed in Part 2, and analyzes whether the animal property form coheres with these justifications. ${ }^{103}$

Justificatory theories of private property are canvassed in Alexander and Peñalver's text, An Introduction to Property Theory. These justifications can be conceived as operating within two broad categories, each of which describes private property as generating a distinct form of 'good'. Internal wellbeing theories understand private property as playing an irreplaceable role in the development of internal goods such as individual flourishing or free personality. External wellbeing theories justify private property on the basis that individual proprietorship maximizes society's available and productive resources. By assigning private control of resources to discrete individuals, the private property system generates incentives to preserve and productively cultivate resources. By dealing with property theories through the categories of internal and external wellbeing, this article addresses each of the theories covered by Alexander and Peñalver. ${ }^{104}$

101. The following analysis draws on John Rawls, 'Two Concepts of Rules' (1955) 63(1) The Philosophical Review 3 ('Two Concepts') and Patrick Emerton and Kathryn James, 'The Justice of the Tax Base and the Case for Income Tax' in Monica Bhandari (ed), Philosophical Foundations of Tax Law (Oxford University Press 2017) 125. Rawls articulates his ideas surrounding institutional design using the notion of a practice, such as promising or punishment. This article adopts Emerton and James' understanding of institutions as 'an important class of practices': at 128 .

102. Rawls contrasts his preferred conception of rules (the practice conception) with the summary conception. Under the latter conception rules operate as guides or rules of thumb that direct a person's conduct. This is unsatisfactory because it assumes a single office within the institutional framework and elides the two distinct institutional roles of those who create the rules and those who follow them: Rawls, Two Concepts (n 101) 19, 28.

103. The conceptual distance that exists between property rules and the overarching goals of the private property institution raises complex questions surrounding precisely how legal rules work to serve an institution's overarching goals. This article does not analyze this issue in any detail.

104. Aristotle's work (largely presented through the contemporary Aristotelian Martha Nussbaum), Hegelian and Kantian property theory are presented as internal wellbeing theories. Utilitarian and Lockean theories are categorized as external wellbeing theories. 


\subsection{Internal Wellbeing Theories}

Internal wellbeing theories can be understood through a consideration of Aristotelian philosophy. ${ }^{105}$ Aristotle's concern for human wellbeing led him to advocate a system of private ownership as a means to secure both internal and external wellbeing. Focusing now on internal wellbeing, ${ }^{106}$ Aristotle identified the private property system as one that enables individuals to exercise certain virtues and provides a source of personal pleasure and pride. ${ }^{107}$ This article considers the interaction between animal property and internal wellbeing theories through the lens of contemporary Aristotelian Martha Nussbaum and German philosopher George Hegel. ${ }^{108}$

Nussbaum's theory is generally concerned with the flourishing of all forms of life that possess abilities and needs. While strictly a theory of justice, Nussbaum's theory demands a system of private property in order for flourishing to be achieved and has, for this reason, been treated as a contemporary approach to Aristotle's work on property. ${ }^{109}$ Her theory presents an opportunity to critique internal wellbeing property theories that situate animals as individuals whose wellbeing must be secured. As will be seen, a flourishing state cannot be secured for those who are classified as a means to serve the capabilities of others.

Unlike Nussbaum, Hegel regards objects as a necessary component in the development of human personality. ${ }^{110}$ This concern for the ethical development of free will grounds Hegel's account within concepts that are essentially, if not distinctly, human. In this way, the problems presented by animal property that arise with respect to Nussbaum's theory do not apply to Hegel's. Nevertheless, animal property does not conform to Hegel's understanding of property because animals possess purposes that do not originate from, and are not understood by, humans. This analysis is also applicable to the work of Immanuel Kant. These ideas are scrutinized in the remainder of this section.

\subsubsection{Capability Theory and Property}

3.1.1.1 The theory Nussbaum's capability theory is primarily a theory of justice. ${ }^{111}$ Originally grounded in notions of human dignity, Nussbaum's capabilities represented core human entitlements that allow people to realize what they are 'actually

105. Alexander and Peñalver (n 13) 81.

106. Aristotle's concern with external goods will be considered below in section 3.2.

107. Richard Kraut, Aristotle (Oxford University Press 2002) 330; Fred Miller, Nature, Justice and Rights in Aristotle's Politics (Clarendon Press 1995) 321.

108. Alexander and Peñalver identify Nussbaum as a contemporary Aristotelian, using her work as a modern application of Aristotle's property theory: (n 13) 87-89.

109. See ibid chapter 5.

110. The account of Hegel's theory of property presented here draws primarily on Jeremy Waldron's reading of Philosophy of Right in The Right to Private Property (n 62). Waldron and Alexander and Peñalver's texts treat Hegel's theory as a justification for private property. Nonetheless, other scholars treat Hegel's work as a description of how property arises: see David Carlson, 'How to Do Things with Hegel' (1999-2000) 78 Texas Law Review 1377, particularly at 1391.

111. Note that other capability theories exist. See, for example, Amartya Sen, Commodities and Capabilities (Oxford University Press 1987). Attempts have been made to extend Sen's capabilities approach to the nonhuman animal sphere, but Sen has not engaged in such extensions himself: see Ani Satz, 'Animals as Vulnerable Subjects: Beyond Interest-Convergence, Hierarchy and Property' (2009) 16 Animal Law 65, 112-17. 
able to do and be'. ${ }^{112}$ One of these capabilities is property-holding. Nussbaum's original capabilities approach encompassed ten central capabilities that gave 'shape and content to the abstract idea of dignity'. ${ }^{113}$ Dignity, for Nussbaum, roughly equates to a life of 'truly human functioning' that recognizes the individual's 'corresponding needs for flourishing'. ${ }^{114}$ Later, Nussbaum extended her capability theory to sentient nonhuman animals. This application presents some problems where animals are objects of property.

Nussbaum's theory demands extension to nonhuman animals because the theory's basic moral concern is for 'the dignity of a form of life that possesses both abilities and deep needs' ${ }^{115}$ Capabilities are the linchpin of Nussbaum's theory of justice, making other characteristics of the subject (for example, their species) of peripheral importance only. ${ }^{116}$ Human flourishing is clearly not the same as animal flourishing. Nonetheless, Nussbaum identifies elements of a dignified existence that are common for both human and nonhuman animals, such as freedom from pain and freedom to act in ways that are characteristic of their species. ${ }^{117}$ Using these foundations to inform her analysis, Nussbaum sketches a basic capabilities framework in the human and animal contexts. ${ }^{118}$

Nussbaum's tenth capability, namely, 'control over one's environment', is relevant to the issue of animal property. ${ }^{119}$ This capability has application in both the human and animal contexts and has two components: one political and one material. ${ }^{120}$ For humans, the material component encompasses the capability 'to hold property (both land and moveable goods) and have property rights on an equal basis with others'. ${ }^{121}$ At this point an obvious tension emerges in Nussbaum's theory, insofar as animal property is concerned. Private property is justified because it serves the realization of a flourishing state. Animals are proper participants, along with humans, within the capabilities framework. But where animals are the object of property rights, human capabilities are served while animal capabilities are stunted. This outcome does not conform to Nussbaum's theory. The capabilities approach is concerned to secure the flourishing of all 'form[s] of life that [possess] both abilities and deep needs'; it does not contemplate two classes of participants. ${ }^{122}$ Nussbaum states that 'animals should surely not be treated like mere objects for humans' use and control: their own flourishing and their own ends should be held constantly in view ... they

112. Martha Nussbaum, Frontiers of Justice (Harvard University Press 2006) 70 ('Frontiers'). 113. ibid 75 .

114. ibid 74, 327. The link between personal property and human flourishing is also explored in Margaret Radin, 'Property and Personhood' (1982) 34 Stanford Law Review 957 and Margaret Radin, 'Market-Inalienability' (1987) 100 Harvard Law Review 1849.

115. Nussbaum, Frontiers (n 112) 346.

116. For Nussbaum, the importance of species identity seems to manifest in determining the types of capabilities that must be secured. Only basic or innate capabilities must be secured, and these capabilities are specified by a 'species norm': ibid 361 .

117. ibid 326.

118. See ibid 393-400.

119. Note that this capability was not included in Nussbaum's earlier work, but emerged in Martha Nussbaum, Women and Human Development: The Capabilities Approach (Cambridge University Press 2000).

120. For animals, the analogue of the property right is respect for the territorial integrity of animal habitat, whether domestic or 'in the wild': Nussbaum, Frontiers (n 112) 399.

121. ibid 77.

122. ibid 346. 
may be treated as we currently treat children and many people with mental disabilities, who have a large menu of rights and are in that sense far from being "mere property", 123

3.1.1.2 Human capabilities and animal capabilities Property status operates as an inappropriate burden on animals' abilities to realize their own capabilities. It erases the interests of animal 'objects' and identifies them as the subject of human property rights that flow from the capability to hold property. This is notwithstanding protections created by welfare laws that restrict the exercise of property rights with respect to animals. ${ }^{124}$ Property status identifies the object of property, first and foremost, as being at the disposal of the owner. The interests and capabilities of objects cannot be meaningfully balanced with the interests and capabilities of right-holders because each entity enjoys a fundamentally different legal standing. One is a right-holder seeking to act upon her legally sanctioned capability to hold property and resulting property rights; the other is the object of property itself. ${ }^{125}$

The human capability to control one's environment through property-holding means that animal property may only realize their own capabilities within the remit allowed by humans in exercising their capabilities to flourish. Imagine a person who holds a spider-monkey as an exotic pet. Through realizing their capability to control their environment, the human owner may decide (among other things) to confine the monkey to a single room. But the spider-monkey has its own capabilities, including the 'senses, imagination and thought' capability. ${ }^{126}$ This capability encapsulates the monkey's need to attain pleasurable experiences and avoid non-beneficial pain, ${ }^{127}$ and is repressed when its owner exercises their capability to control their environment in this way. ${ }^{128}$ The monkey's status as property prevents it from exercising its own capabilities where they conflict with the capabilities of its owner. In this way, realization of the owner's capabilities forecloses the opportunity for the spidermonkey to engage in characteristic activities: it cannot interact with other monkeys, forage or inhabit an arboreal environment. The monkey cannot flourish. Discussion of animal capabilities as a demand of justice only becomes coherent if animals are not chattels.

To address the apparent inability of animal property to flourish, Nussbaum proposes that 'the best solution might be to focus initially on good treatment during

123. ibid 376-77.

124. See Francione (n 3) 24-26.

125. These ideas have been explored by Francione who recognizes that 'the framework of legal welfarism contains numerous normative considerations that render empty, for the most part, any attempt to "balance" the interests of humans with the interests of animals: see generally Francione (n 3), and specifically at 18 . The fundamental problem lies in attempting to balance 'two very different entities': right-holders and entities (animals) deemed incapable in law of having rights: at 22. Because animals are property, the 'winner' of disputes between the interests of humans and animals is 'predetermined by the way in which the conflict is conceptualised in the first place': at 24 .

126. Nussbaum, Frontiers (n 112) 396-97.

127. ibid 396.

128. There is evidently a level of idealism in Nussbaum's work. Many humans are unable to control their environment, and some animals may enjoy greater realization of their capabilities (for example, the bodily health capability, which encompasses adequate nutrition and shelter) than do some humans. 
life and painless killing'. ${ }^{129}$ This account is unsatisfactory because it collapses the capabilities approach into what is essentially a pragmatic, anodyne argument and drastically weakens it. ${ }^{130}$ Moreover, this 'solution' does nothing to resolve the incoherence of an animal property form for Nussbaum's extended capability theory.

Where animals are liberated from their property status, their potential to gain meaningful access to species-specific capabilities becomes possible. This is not to say that conflicts between capabilities will disappear. ${ }^{131}$ Rather, where animals are not property, the reconciliation process is not predetermined in favour of the realization of human capabilities. Consider a sight-impaired person who secures the assistance of a guide-dog to enable the exercise of their capability for 'senses, imagination and thought'. The guide-dog is beholden to the human it assists, so its capacity for play, for example, is severely diminished. ${ }^{132}$ However, Nussbaum's capabilities approach strives for the guarantee of a threshold or minimum level of basic capabilities. ${ }^{133}$ Where the guide-dog is an equal participant in the capabilities framework, conflicts are resolved through assessing the merits of relevant capabilities in their contribution to securing a dignified life above the minimum standard, and not on the basis of a value-laden hierarchy that privileges certain forms of life. This would not be the case if a participant (human, dog, monkey, whatever) was an object of property because property status necessarily identifies objects as a means to serve the capabilities of others. Animal flourishing cannot be secured where the realization of their capabilities is entirely dependent on the choices of other participants (humans) in exercising their own capability to hold property.

\subsubsection{A Hegelian Property Analysis}

3.1.2.1 Hegel's theory Hegelian property theory conceives of property as a necessary component in the development of 'free will' or 'personality'. The free will is one that recognizes, but can abstract itself from, its needs, desires and inclinations. ${ }^{134}$ It is obtained through embodiment of the individual's will in property. Hegel's theory is fundamentally developmental: individuals are initially controlled by their own needs and desires. They obtain their first experience of freedom through the ability to abstract themselves from each need or desire, comprehend the 'pure abstracted thought' of themselves and relate this understanding back to their needs and inclinations. ${ }^{135}$ Through this abstraction, the personality perceives

129. Nussbaum, Frontiers (n 112) 402-03.

130. Andy Lamey, 'Frontiers of Justice: Disability, Nationality, Species Membership' (2007) 48(4) Philosophical Books 376, 379. See also Satz (n 111) 112.

131. However, Nussbaum anticipates that conflicts between capabilities will be rare, at least in the human context. The existence of conflict suggests that 'society has gone wrong somewhere': Frontiers (n 112) 401.

132. The limitations placed on the exercise of capabilities by carers have also been recognized in the human context: see ibid 170.

133. ibid 70 .

134. Waldron (n 62) 352.

135. ibid. In this state of nature, individuals are not free because each drive is 'bent solely on its own satisfaction': Richard Davis and Milwaukee Wi, 'The Conjunction of Property and Freedom in Hegel's Philosophy of Right' (1989) 43(1) Zeitschrift für philosophische Forschung $111,115$. 
itself as independent from its circumstances because its needs and impulses do not dictate what the individual is or does. ${ }^{136}$

Initially, the will is embodied in the human subject and is merely an aspect of a person's inner and subjective life. ${ }^{137}$ But as the developmental process progresses, the will must be transformed from the purely subjective to the objective. This is achieved through embodiment of free will in the external world. ${ }^{138}$ Hegel identifies the 'public world of material objects' as an appropriate platform for this 'initial excursion of free will'. 139

The notion of embodiment is, on its face, 'extremely obscure'. ${ }^{140}$ An individual's will is embodied in an object where (a) their will has made a difference to the object (in the sense that something about the object can only be understood by reference to the person's will), and (b) the object itself affects the person's willing. ${ }^{141}$ The bidirectional relationship of embodiment may take three forms: possession, use and alienation. ${ }^{142}$ Alienation is the most important form of embodiment because it proves the will can live without the object. ${ }^{143}$ Alienation to others requires contract, which, for Hegel, is the 'foundation of property itself'. ${ }^{144}$

It is important for personality to be embodied in the external world for three reasons. ${ }^{145}$ First, property ownership 'makes consciousness concrete'. ${ }^{146}$ In manipulating and working on an object, the individual is subject to a degree of mental discipline because steps undertaken or actions carried out in the present make available certain

136. Alan Patten, 'Hegel's Justification of Private Property' (1995) 16(4) History of Political Thought 576, 582.

137. Hegel's philosophy understands the will as necessarily being embodied at each stage of ethical development: Waldron (n 62) 370.

138. ibid 359.

139. ibid 356.

140. ibid 360. For a contemporary, 'intuitive' personhood theory that draws inspiration from Hegel, see Radin, 'Property and Personhood' (n 114) 959. Radin asserts that individuals need 'some control over resources in the external environment' to achieve proper self-development because 'most individuals possess certain objects they feel are almost part of themselves': at 959. 141. Waldron (n 62) 370.

142. ibid 360-70. See also Carlson (n 110) 1382-85.

143. Carlson (n 110) 1385. Anglo-centric readings of Hegel often focus on the individualistic aspects of his theory, but its communitarian elements are fundamental. Both possession and use of objects 'confirm the necessity of the object and hence the unfreedom of the self': at 1390 . Alienation frees the individual of dependence from objects, and presupposes the existence of other persons who may take possession.

144. ibid 1391. As Carlson further explains, '[u]ntil contract, the free self's claim to property was criminal because it denied the right to any other free self. Retroactively, property became legitimate when it was bestowed on the free self by the other'.

145. This article supplements Waldron's account of the importance of embodiment in personal property with that of Patten. For Waldron, embodiment (a) makes consciousness concrete through imposing a certain mental discipline on the will, and (b) mediates recognition by other persons: Waldron (n 62) 371-77. Patten criticizes Waldron's account for downplaying two important aspects of Hegel's philosophy: his notion that 'the person is an object to himself in his property' and his account of mutual recognition: Patten (n 136) 580. Nevertheless, these ideas are captured in Waldron's account of an object 'registering' the will embodied in it, and his focus on embodiment mediating recognition: Waldron (n 62) 371-77, quotation at 373 . The interpretations are best understood as complementing each other and are presented together here.

146. Waldron (n 62) 371-74, quotation at 371. 
future steps or actions, and preclude the possibility of others. ${ }^{147}$ To illustrate this point, Jeremy Waldron uses the example of a chair. Once certain actions have been taken in making the chair, such as cutting the pieces of wood to form chair legs, other possibilities with respect to the wood, such as making a table, become impossible. The 'timber has been cut into lengths too small for a table' ${ }^{148}$ In this way, the timber itself constrains the owner's willing (relationship (b) above). The object 'registers' the physical manifestation of the will, imposing purpose, permanence and stability on it. ${ }^{149}$

Second, the ability to see one's will embodied in the objects one owns or works upon benefits the individual. ${ }^{150}$ Where the will is externalized in an object, one can see concrete, objective evidence of their independence from a given set of circumstances. This assists in the development of free will because a person can 'see that the environment need not dictate to him what he shall be or do, that he can impose his own plans and purposes on his situation'. ${ }^{151}$ Finally, embodiment of the will in property plays an integral role in mediating recognition by others. ${ }^{152}$ Where the will is embodied in an external object, not only can the individual confirm their own sense of independence, but other persons can perceive the alterations and transformations registered in the external object as a manifestation of the owner's free will. ${ }^{153}$

3.1.2.2 Underpinning assumptions Hegel's theory of private property makes at least two assumptions: first, that the world of material objects is an 'arena in which the externalisation of freedom is permissible'; second, that the world of material objects is not 'too lowly or sordid' an arena for externalization to take place. ${ }^{154}$ Animal property presents a challenge for the first of these assumptions.

Hegel identifies the world of material objects as the appropriate realm for embodiment of free will because things are not 'ends-in-themselves'. ${ }^{155}$ This article uses Waldron's related concept of 'purposes' or 'projects' to analyze this idea. ${ }^{156}$ Waldron states that one proves a thing is not a 'thing in itself' by 'endowing the object with a purpose which is not its own; when this is done, we recognise that the object is such that the only purpose it could have is a purpose given to it by a human being'. ${ }^{157}$ Waldron illustrates his point by reference to the institution of slavery. Slavery is

147. ibid 371-72.

148. ibid 372 .

149. ibid.

150. This point is implicitly recognized by Waldron (ibid) and explicitly recognized by Patten ((n 136) 584-86) in his account of self-perception and self-development.

151. Patten (n 136) 585.

152. Waldron (n 62) 375-77; Patten (n 136) 595.

153. Patten (n 136) 598. Hanoch Dagan and Avihay Dorfman similarly identify the value of private property as lying in 'the respect from others that ownership implies ... for the owner's subjectivity and her right to self-determine according to her own conception of the good': 'The Human Right to Private Property' (2017) 18(2) Theoretical Inquiries in Law 391, 403. See also Morris Cohen, 'Property and Sovereignty' (1927) 13 Cornell Law Review 8.

154. Waldron (n 62) 356.

155. ibid.

156. By using the language of 'ends in themselves', Hegel reveals the points of similarity between his own theory and that of Kant's. The language of 'purposes' also resembles Kant's work in Critique of Judgment, but the similarities do not go very far: see footnote 175 of this article.

157. Waldron (n 62) 356 (emphasis in original). 
wrong because the first assumption of Hegel's argument is not met: the will of the master attempts to externalize itself in an arena where externalization is not permissible. ${ }^{158}$ Externalization of the master's will in his or her slave property is not permissible because this is not the only way the slave could be 'imbued with purpose'. ${ }^{159}$ Animal property produces incoherence for Hegel's theory for similar reasons.

3.1.2.3 The 'purposes' of inanimate property The idea that inanimate property has 'purpose' is not intuitive, so will be elucidated through Waldron's example of a chair. Imagine that a person (George) builds the chair using timber. George's chair is sturdy, with a solid back, armrests and a cushion in the seat. These characteristics are solely referable to George's will, and the overall process of fashioning the raw materials (timber, nails etc.) into a chair is a purpose that could only originate from a human will. Nevertheless, there are some characteristics of the chair that are not referable to George's will, such as the grain and strength of the timber. Waldron's reading of Hegel seems to miss this relation in the assertion that the object 'in its affected state' affects the will, ${ }^{160}$ because objects can affect the will in their unaffected, natural or initial state. While the grain or strength of timber cannot readily be described as a 'purpose' of the timber, these features are certainly characteristics of the timber, and these characteristics yield discrete purposes only. Namely, they limit the purposes a human may give the timber. This analysis reveals that inanimate objects have some purpose independent of the human will. They possess some purposes that derive from nature.

While Waldron's reading of Hegel apparently elides the possibility that nature gives purpose to objects, this possibility was explicitly recognized by Hegel's contemporary, Fichte. Under Fichte's theory, ${ }^{161}$ individuals have a right to 'whatever constitutes a social condition of the possibility' of personality. ${ }^{162}$ The main social condition demands individuals be immune from 'interventions by others [in] the sphere of the external world' in which they act. ${ }^{163}$ Private property secures this social condition by giving individuals a right to exclusive access and control over some resource. Interventions within the external sphere in which an agent acts inhibit the development of personality because interventions by others prevent the agent from connecting changes in an object with their own will. ${ }^{164}$ Alan Patten further explains that 'where there are no interventions by others, changes in the object can be explained only by [the will's] purposes or by nature'. ${ }^{165}$ This statement reveals Fichte's conception of nature as knowable to humans. ${ }^{166}$ Personality develops through the individual's actual perception of their own agency in a concrete way. ${ }^{167}$ Assuming that interference by other agents is impermissible (because

158. ibid 357.

159. ibid.

160. ibid 370 (emphasis added).

161. As expressed in JG Fichte, 'Grundlage des Naturrechts' in IH Fichte (ed), Johann Gottlieb Fichtes sämmtliche Werke (de Gruyter 1745-46) and presented in Patten (n 136).

162. Patten (n 136) 590.

163. ibid.

164. ibid 593.

165. ibid.

166. ibid, citing Fichte (n 161) 114-16.

167. Patten (n 136) 594. The idea of making consciousness concrete is also present in Waldron's reading of Hegel: Waldron (n 62) 371. 
objects are privately owned) and the object's natural purposes are known to the individual, the individual perceives their agency in the external world because they can identify which purposes embodied in the object are referable to their own will.

In Philosophy of Right, Hegel provided a fairly thin argument for a system of private property. ${ }^{168}$ Waldron identifies the relation between the mind and object over time as doing the 'real work' for Hegel's argument. ${ }^{169}$ Once the will is embodied in a material object, this 'constrain[s] or determine[s] the actions that [one] can perform on or with [an object] later' ${ }^{170}$ If others could work upon or possess the same object, the will would be unable to plan or apply itself to achieve the realization of certain outcomes with respect to the object because the will of another could be embodied and registered in the object at any time. Individuals need a private sphere of influence to reap the benefits of discipline of the will and obtain a concrete perception of the will as independent. ${ }^{171}$ This argument is based on similar ideas as those that arise in Fichte's work, and Patten suggests that Hegel may have taken something like Fichte's account for granted when developing his theory. ${ }^{172}$ Both Hegel and his readers would have been familiar with Fichte's work, ${ }^{173}$ and there is explicit recognition in Hegel's writing that the development of personality is a process that renders nature knowable and familiar. ${ }^{174}$ Interpreting Hegel as cognizant of the constraints imposed by nature requires expansion of Waldron's original statement: embodiment of the human will in material objects is appropriate where the only purposes the object can exhibit are human purposes or natural purposes (being characteristics derived from nature that are known to humans). Applying Hegel's theory to animal property, animals are an unsuitable object of property rights because they are imbued with purpose from other sources. ${ }^{175}$

168. Waldron (n 62) 373.

169. ibid.

170. ibid.

171. Waldron (n 62) 371-74; Patten (n 136) 586-87.

172. Patten (n 136) 594.

173. ibid.

174. Waldron extracts the following translation from Hegel: 'Our intention, however, is rather to grasp, to comprehend Nature, to make her ours, so that she is not something alien and yonder': (n 62) 356. Note that Waldron's treatment of this statement makes a slightly different point to the one made here. Waldron says that, through the domestication of nature, humans become familiar with nature, begin to feel 'at home' in their environment and recognize that nature is not 'distinct in kind' from the human mind: at 357. Waldron's gloss seems to collapse the distinction between human purposes and natural purposes that are knowable by humans. The approach adopted in this article accommodates the independent existence of natural characteristics or purposes, but recognizes that they provide no barrier to externalization of the will in property when known to humans.

175. The language of 'purposes' bears resemblance to Kant's Critique of Judgment, but the meaning of the word as used by Kant is quite different. Kant defines a purpose as 'the object of a concept insofar as we regard this concept as the object's cause': Immanuel Kant, Critique of Judgment [trans. Werner Pluhar] (Hackett Publishing Company 1987) 220. The paradigm of a purpose is a human artefact (for example, George's chair). This is the extent of similarity. Kant refers to animals and plants as 'natural purposes' because these organisms are 'both cause and effect': at 371. In contrast, the language of 'purposes' in this article refers to the 'projects' or intentions of humans and animals, and the deterministic characteristics imposed by nature on objects ('natural purposes'). 
3.1.2.4 The 'purposes' of animal property To illustrate the differences between the purposes of animal property and inanimate property, this section draws upon Tom Regan's example of Fido the dog. ${ }^{176}$ Imagine that Frey owns Fido and that Frey is an attentive owner, who ensures that Fido's general needs are met. Fido sometimes scratches at the door, and once the door is open, Fido runs outside, digs up a bone he has previously buried and proceeds to gnaw at it. As this section will demonstrate, this behavior (a 'purpose' or 'project') derives from Fido himself. It does not arise from humans or knowable natural characteristics.

As a preliminary matter, the example of Fido and Frey should be justified as an appropriate core case on which to rest the analysis of animal purposes. As illustrated by the sketch of Fido and Frey's interaction, it is at least arguable that Fido has his own projects. But there are other (numerically significant) circumstances in which animals probably cannot manifest their own purpose(s). Consider battery hens and other animals housed in intensive confinement systems. Their short lives are so closely controlled by humans that their purposes are probably limited to human purposes or knowable natural purposes. ${ }^{177}$ Nevertheless, the Fido example presents an appropriate core case. Considering the role of property in the development of (human) personality, we realize that not all humans can develop the sort of free will that Hegel envisaged because not all persons own property. ${ }^{178}$ Propertylessness presents a serious concern for Hegel's theory because the propertyless individual is 'stranded in their natural subjective immediacy'. ${ }^{179}$ Yet the numerical significance of the 'propertyless' does not destabilize Hegel's core case of persons who do own meaningful objects of property. ${ }^{180}$ Following Hegel's lead, it is permissible to choose a core case where it is at least possible for the subject to develop projects (because, in the human case, they own some property; or, in the animal case, they are not subject to a regime of complete human control and confinement). An argument that attempts to dismiss animal purposes on the basis that some animals cannot manifest their own projects misses the point in this regard. Many persons cannot develop personality in the way Hegel suggests, yet his theory remains a central justification of private property.

Animal purposes are not human purposes The process of domestication raises questions regarding whether animals that appear to pursue their own projects are simply embodying the will of their owner. First, the degree of control exercised over certain animals through the historical process of domestication may suggest that all supposed animal projects are really the projects of humans who orchestrated selective breeding processes. Second, domestication has the result that many animals live out their lives

\section{Regan (n 2).}

177. See Singer (n 10) 98-141 on industrial farming practices.

178. For example, Marx's proletariat class comprised the 'immense majority': Karl Marx, The Communist Manifesto, ed Friedrich Engels (The University of Adelaide Library 2008) chapter II. A significant proportion of the current global population live in poverty: United Nations, 'Ending Poverty' Global Issues (Factsheet, 17 November 2020) <www.un.org/en/sections/ issues-depth/poverty/>.

179. Waldron (n 62) 377-86, quotation at 378.

180. The word 'meaningful' is used because propertylessness is 'not the bare absence of any relation of possession and control between a person and an object. Rather, it is the condition of a person whose will, driven as it is by natural needs for subsistence, is unable to find an embodiment in external objects. This is certainly the condition of the beggar, even though he "owns" his rags and begging bowl': Waldron (n 62) 386. 
under human custody. The temporally immediate control owners exert over their animal property raises the same tension as that of historical domestication processes: are the projects animals manifest their own, or are they the expression of their owner's purposes?

Animal purposes are not human purposes because animals engage in behaviors that are not fully referable to the human will and to that extent escape human knowledge, cognition and control. Consider the example of Fido and Frey. The act of scratching at the door could lead to Fido manifesting various purposes upon being let outside. He could dig up his bone, or decide to dig for the sake of it; bark at the neighbor's cat, or curl up in his favorite spot under a bush. From Frey's point of view, Fido's behavior is arbitrary. The specific purpose that Fido does pursue (for example, barking at the cat) is indeterminate from the human perspective. Hegel's account of the development of personality involves a transition from arbitrary operation of the will to a state of true freedom. ${ }^{181}$ Fido's self-directed behaviors cannot be the manifestation of Frey's own purpose(s) because such behaviors are arbitrary from Frey's perspective. The same reasoning precludes an interpretation of Fido's behavior as referable to the historical process of domestication. The plurality of projects Fido could pursue upon being let outside conflicts with a characterization of animal behavior as the direct manifestation of domestication processes. Domestication has not narrowed animal behaviors to the extent that each behavior derives from humans' historical breeding purposes.

Animal purposes are not natural purposes The question of whether animal purposes are natural purposes is fundamentally an issue of animal autonomy. Natural purposes in the Hegelian/Fichtean sense are knowable and familiar in a sense that can be contrasted with human agency. Yet animals, in a manner similar to humans, express selfdirected, purposive behavior that is unknowable or unpredictable to other individuals and demonstrates a level of originality or ingenuity. Evidence of these capabilities is found in the literature on animal autonomy, and specifically in Regan's account of preference-autonomy. ${ }^{182}$

Regan identifies an individual as autonomous when they possess preferences and the 'ability to initiate action with a view to satisfying' those preferences. ${ }^{183}$ Most animals are likely to possess desires or goals, and so display autonomy in the preference sense. ${ }^{184}$ Indeed, developments in animal behavior science indicate that some animals may be autonomous in the more stringent sense of having the capacity to "choose

181. Thom Brooks, Hegel's Political Philosophy (Edinburgh University Press 2009) 31.

182. Other interpretations of autonomy exist: see Natalie Thomas, Animal Ethics and the Autonomous Animal Self (Palgrave Macmillan 2016) 69-95, where eight different types of autonomy are articulated, being adopted from Nomy Arpaly, Unprincipled Virtue: An Inquiry into Moral Agency (Oxford University Press 2003). Relational approaches to autonomy are particularly useful in the animal context, as they recognize interdependence as a key component of autonomy: see, for example, Jennifer Nedelsky, Law's Relations: A Relational Theory of Self, Autonomy and Law (Oxford University Press 2012). This article is not concerned with the 'correct' notion of autonomy, but uses the literature on preference-autonomy to demonstrate that animals are capable of rational, preference-guiding behavior that is not amenable to human knowledge.

183. Regan (n 2) 84-85.

184. Regan thinks it is clear that animals have preferences that influence their behavior: ibid $57-60$. 
upon rational reflection over [their] options' ${ }^{185}$ Animals that are autonomous at the preference or some higher level manifest purposes that are unknown to humans. They give themselves purpose by acting intentionally to give effect to their preferences or projects.

Regan's account of preference-autonomy in animals is anecdotal and dialectic, further developing his example of Fido the dog. Regan attributes to Fido the belief that choosing a bone will satisfy his desire for a certain flavor because Fido selects a bone and not some other object. The content of his belief, that choosing a bone will satisfy his desire for a gustatory flavor, reveals that Fido has expectations or beliefs about the future. These expectations can exist in more complex forms that dispel any necessary barriers to the conclusion that Fido can act intentionally. ${ }^{186}$ Consider Fido's journey from scratching at the door to satisfying his desire for a certain taste. He scratches on the door to get outside, to dig up a bone, access the bone and then satisfy his gustatory preference. ${ }^{187}$ Fido clearly has certain expectations. In acting upon these expectations to satisfy some preference, Fido behaves intentionally.

As already noted, Fido's act of scratching at the door gives rise to a number of possible, alternative pathways. Frey (and other agents) do not know what Fido will do once he is let outside. This precludes a characterization of Fido's purposes as natural purposes. The reason Fido's purposes are not natural purposes is thus the same reason that his purposes are not human purposes: Fido's behavior is unknown to humans. He does not act in a stimulus-response or determinative way, which distinguishes Fido from other objects that have natural purposes knowable to humans (for example, the timber's grain). Fido is the only being who knows why he scratches on the door. This knowledge is informed by Fido's own expectations and intentions: he has a particular project he wishes to manifest (chew on a bone, not bark at a cat) and in pursuing that project, informed by his own preferences and expectations, he imbues himself with purpose. ${ }^{188}$

The capacities that Regan attributes to animals are supported by science. For example, domestic pigs are capable of revising their behavior when faced with difficult or complex circumstances by learning to use mirrors to locate a hidden food source. ${ }^{189}$ Other research demonstrates that pigs can overcome attempts at exploitation by other group members to protect food resources. ${ }^{190}$ These abilities necessarily entail

185. David Judd and James Rocha, 'Autonomous Pigs' (2017) 22(1) Ethics \& The Environment 1,2 .

186. Regan (n 2) 74.

187. ibid.

188. This is not to say that Fido cannot embody human purposes. If Frey told Fido to go outside, Fido would seem to be embodying Frey's purpose in so going. But it is not the case that Fido's purposes may only derive from humans. For further literature on animal autonomy, see, for example, Steven Wise, Drawing the Line: Science and the Case for Animal Rights (Basic Books 2003) and Thomas (n 182).

189. Pigs that were inexperienced with mirrors looked behind the mirrors for food. Experienced pigs were able to use the mirrors and locate the food source within 30 seconds: Donald Broom, Hilana Sena and Kiera Moynihan 'Pigs Learn what a Mirror Image Represents and Use it to Obtain Information' (2009) 78(5) Animal Behaviour 1037. Note that smell was controlled for.

190. Suzanne Held et al, 'Foraging Pigs Alter Their Behaviour in Response to Exploitation' (2002) 64 Animal Behaviour 157; Judd and Rocha (n 185) 6. In the study, one pig was informed of the location of a food resource, and another pig was not. The uninformed pig 
possession of beliefs about the future, and produce dynamic behaviors as the product of the animal's individual perception and expectations. These beliefs escape immediate or intuitive human cognition and reveal (a) humans' inability to know animal projects in the same way that a human understands the deterministic characteristic of a timber's grain, and (b) animals' ability to imbue themselves with purpose. ${ }^{191}$ These conclusions surrounding autonomy and animal projects extend beyond domestic animals and also encompass animals classified as 'wild', that become the subject of qualified property rights when brought under human control.

Together, the scientific and philosophical literature provides good reason to think that animal behavior is not knowable and familiar in the Hegelian/Fichtean sense. Indeed, it suggests that animals give themselves purpose. For Hegel, the institution of private property exists to facilitate the development of human personality. This involves embodiment of the will in property. Externalization of the will in an object is permissible where the object may only derive purpose from humans or nature. But animal purposes may arise from the animal itself. Hegelian property theory does not accommodate animals as an object of property.

\subsubsection{A Note on Kantian Property Theory}

Kant's theory of property encounters problems when extended to animals for similar reasons as those that arise for Hegel. Like Hegel, Kant's theory is primarily concerned with individual freedom. Freedom is the innate right, 'belonging to every human being by virtue of his humanity'. ${ }^{192}$ Persons are free where they can decide which goals and ends they will pursue. Property rights enable individuals to pursue their goals through external things and meaningfully exercise their capacity for free choice. Kant's conception of property is 'a right to use [an] object as a means to some personal end'. ${ }^{193}$ Objects fulfil their purpose of facilitating free choice if a person, regardless of the content of their purpose, can use the object to secure those purposes, and the object is subject to the individual's choice as a means to secure those purposes. ${ }^{194}$ Animal property does not conform to this description because animals' capacity for self-directed purposive behavior interferes with the ability for humans to impose their own purposes on them. As explored in the context of Hegel's theory, the contemporary literature on animal autonomy and cognition provides good reason to conclude that animals are purposive beings. Purposive beings may not be 'at one's disposal in pursuing one's own ends' because they may be otherwise engaged in pursuing their own purpose. ${ }^{195}$

expected to increase its foraging efficiency by closely following their informed companion. The informed pig expected the uninformed pig to follow it and access the food resource if the uninformed pig could see the informed pig's movement. See also Suzanne Held et al, 'Domestic Pigs, Sus scrofa, Adjust their Foraging Behaviour to Whom they are Foraging with' (2010) 79 Animal Behaviour 857.

191. See also K Laughlin and M Mendl, 'Pigs Shift Too: Foraging Strategies and Spatial Memory in the Domestic Pig' (2000) 60 Animal Behaviour 403.

192. Alexander and Peñalver (n 13) 70.

193. ibid 72.

194. ibid 74.

195. ibid 73. The contention that animals are purposive beings is associated with, but not the same as, more general challenges to Kant's well-known designation of animals as 'means to ends': Immanuel Kant, 'Duties to Animals and Spirits' in Lecture on Ethics, L Infield (transl), 


\subsection{External Wellbeing Theories}

If the challenges that animal property present for internal wellbeing theories cannot be answered, one may appeal to external wellbeing theories. External wellbeing theories are concerned with the outcomes produced by the private property institution; unlike internal wellbeing theories, the intrinsic nature of humans and other animals is largely immaterial. ${ }^{196}$ The consequentialist focus makes external wellbeing theories sensitive to changes that occur over time that alter the outcomes produced by private property systems. ${ }^{197}$ For this reason, the classification of animals as property may once have gained support from external wellbeing theories. This is no longer the case in modern liberal economies. The deterioration of valuable resources is now a corollary of the property status of animals.

External wellbeing theories advocate private property as the system that maximizes society's available and productive resources. For convenience, this idea will be called the 'non-deterioration thesis'. Private ownership safeguards against the deterioration of scarce resources (preservation) and encourages their better management and cultivation (production). ${ }^{198}$ Two key ideas motivate this claim: the 'Tragedy of the Commons' and the problem of the 'Free Rider'. The former phenomenon describes a situation where common property is not preserved. ${ }^{199}$ Where land is owned in

(Harper and Row, New York 1963) 239. Kant seems to equate his conclusion that animals are irrational beings with the statement that they are means to ends: "[a]nimals are not selfconscious and are there merely as a means to an end': ibid. To this extent, the challenges posed by animal property flow from their possession of characteristics or capacities (namely, self-directed purposive behavior) that make them unreliable as a means to secure human purposes. The merit of Kant's classification of animals as means to human ends is not the focus of analysis here because not all animals covered by this article (nonhuman vertebrates) are rational in the Kantian sense. For general criticisms of Kant's classification of animals as means to ends, see, for example, Christine Korsgaard, 'A Kantian Case for Animal Rights' in Margot Michael, Daniela Kühne and Julia Hänni (eds), Animal Law - Tier and Rect: Developments and Perspectives in the 21st Century (Dike Publishers 2012) 3 and Christine Korsgaard, 'Kantian Ethics, Animals, and the Law' (2013) 33(4) Oxford Journal of Legal Studies 629.

196. See Alexander and Peñalver (n 13) 17.

197. As recognized by Demsetz in his discussion of the Algonquin Indians in Labrador: see Harold Demsetz, 'Toward a Theory of Property Rights' (1967) 57 The American Economic Review 350-53.

198. These ideas are broadly associated with utilitarianism and utilitarian-influenced theories surrounding welfare economics and the free market. Nevertheless, a wide range of theorists (including those not traditionally regarded as utilitarians such as Aristotle, Locke and Rawls) focus upon the preservation and production of valuable resources as part of the justification for the private property system, and propound theories challenged by the analysis performed in this section. For some representative discussions of theories that fall within the "external wellbeing' category, see Adam Smith, The Wealth of Nations (W Strahan and T Cadell 1976); Joseph Schumpeter, Capitalism, Socialism and Democracy (Harper and Brothers 1942); Friedrich Hayek, Constitution of Liberty (University of Chicago Press 1960); Ludwig von Mises, Human Action: A Treatise on Economics (Yale University Press 1949) chapter XV; Carol Rose, Property and Persuasion: Essays on the History, Rhetoric and Theory of Ownership (Westview Press 1994); John Locke, Two Treatises of Government, (ed.) Peter Laslett (Cambridge University Press 1960); John Rawls, The Laws of People (Harvard University Press 1999) 8, 39 ('Laws of People'); Richard Posner, 'Utilitarianism, Economics and Legal Theory' (1979) 8(1) The Journal of Legal Studies 103, 104; Alexander and Peñalver (n 13) $17,35-56$.

199. Garrett Hardin, 'Tragedy of the Commons' (1968) 162 Science 1243. 
common, rights to use and possession inhere in each owner and rational owners are expected to maximize their gain from using the land. For example, the rational farmer will seek to maximize the number of animals housed on commonly owned land, because each farmer will gain the entire benefit that flows from their animal but only suffer a fraction of the cost (for example, overgrazing). ${ }^{200}$ Each farmer is therefore expected to add another animal to their herd. ${ }^{201}$ The process iterates until the land is ruined.

The system of incentives shifts when resources are individually owned. The allocation of particular resources to discrete individuals means each property owner exclusively obtains the benefits and bears the costs of resource use and can expect this status-quo to continue into the future. ${ }^{202}$ As Rawls identifies, the allocation of responsibility and individuation of loss created by a system of private property incentivizes individuals to guard against resource deterioration and preserve resources through sustainable use. ${ }^{203}$

The problem of the Free Rider occurs where common resources are not productively managed. A free rider 'sits back and lets others do the work' ${ }^{204}$ Assuming there is no power to exclude those who do not contribute to the cultivation of a common, open-access resource, rational actors are incentivized to 'free ride' because they expect to access the benefit of the resource without bearing the costs. The problem occurs where all rational actors eschew the burdensome activity of managing a resource and the property suffers from underproduction. ${ }^{205}$ A system of private property again presents a solution. As recognized by Aristotle, privately owned property receives closer attention and better care than commonly held property. ${ }^{206}$ Individual proprietors expect to receive present and future benefits that flow from owned resources, ${ }^{207}$ and take greater pride in accomplishments concerning their own property. ${ }^{208}$ This system of incentives operates with respect to the individual's resource(s), but at the macro level, private ownership 'increase[s] the common stock of mankind'. 209

These ideas also manifest in the influential work of John Locke, whose theory has had sufficient impact on property thinking in the English-speaking world to warrant explicit mention. Locke's theory of property is typically understood to rely on notions of moral desert, so its categorization as a type of external wellbeing theory requires some explanation. ${ }^{210}$ In the initial state of nature, persons had property in their own person, actions and labor, but not in any particular resource. ${ }^{211}$ When a

200. Alexander and Peñalver (n 13) 20.

201. ibid 19-20.

202. Demsetz (n 197) 354.

203. Rawls, Laws of People (n 198) 8, 39. Posner has, in fact, applied this thinking to animals: '[o]ne way to protect animals is to make them property, because people tend to protect what they own': Richard Posner, 'Animal Rights (reviewing Steven M Wise, Rattling the Cage: Toward Legal Rights for Animals (2000))' (2000) 110 Yale Law Journal 527, 539.

204. Alexander and Peñalver (n 13) 22.

205. ibid.

206. Kraut (n 107) 330; Miller (n 107) 321. Relatedly, Aristotle believed that conflict between persons is reduced where there is clear allocation of ownership.

207. Alexander and Peñalver (n 13) 22.

208. Kraut (n 107) 335.

209. Locke (n 198) chapter 5, section 37.

210. Alexander and Peñalver (n 13) 37.

211. Locke (n 198), chapter 5, section 26. 
person works on a particular resource, their labor is 'mixed' with the object and the object is subsumed within the individual's already owned property - their labor. The crucial step occurs when a person 'join[s] to [the resource] something that is his own', as this 'thereby makes it his Property'. ${ }^{212}$ This aspect of Locke's treatise provides a theory of appropriation that justifies the original acquisition of private property rights. ${ }^{213}$ His justification for the institution of private property - a system whereby many individuals appropriate resources - depends upon satisfaction of the 'Lockean provisos'; ${ }^{214}$ constraints Locke developed to protect the interests of commoners whose position could be impaired by acts of private appropriation. ${ }^{215}$ First, appropriation out of the commons is only permissible where there is enough, and as good left in common for others'. ${ }^{216}$ Second, persons cannot appropriate more than they can use before it spoils. ${ }^{217}$ The provisos reveal that (as with Hegel) certain basic assumptions are built into Locke's thesis; namely, that appropriation from the commons will maximize societal resources. In this way, Locke's articulation of a system of private ownership is fundamentally an external wellbeing theory. Animal property presents some problems for these theories, as articulated in the remainder of this Part.

\subsubsection{The Practicalities of Non-Deterioration for Animals}

A system of private property necessarily assigns owned resources to particular individuals, who then exert some 'sufficient degree of physical control' over the object(s). ${ }^{218}$ This allocative function imposes certain practical constraints upon chattels that the private property system must accommodate: namely, objects must be stable in a temporal and spatial sense. In the animal context, this requirement is replicated and given force by common law rules surrounding fencing and trespass. As explained below, animal objects cannot satisfy these constraints whilst fulfilling the goal of nondeterioration.

The traditional common law notion that some natural resources are not amenable to individual proprietorship provides a preliminary indication of the characteristics required for private ownership. Water, light, air and ferae naturae (wild animals)

\section{2. ibid.}

213. See Carol Rose, 'Possession as the Origin of Property' (1985) 52 The University of Chicago Law Review 73, 73, where she describes Locke's theory as addressing the question of how things come to be owned.

214. Confusion surrounding the normative value of Locke's theory arises from a failure to precisely articulate what the theory is being used to justify - Locke's theory justifies both the acquisition of property rights and a system of private ownership. This article is concerned with justifications for the institution of private property so focuses on the latter aspect of Locke's theory.

215. Alexander and Peñalver (n 13) 39.

216. Locke (n 198), chapter 5, section 26; furthermore, Locke's 'sufficiency provision' (that 'enough, and as good' be left for others) can only be met where property owners cultivate their resources and actually engage in 'resource creation': David Schmidtz, 'The Institution of Property' (1994) 11(2) Social Philosophy and Policy 45.

217. Locke (n 198), chapter 5, section 30.

218. J A Pye (Oxford) Ltd v Graham [2003] 1 AC 419 at 435-36. This 'certain control' 'gives rise to possession and hence a claim to ownership': Rose, 'Possession as the Origin of Property' (n 213) 76, speaking in the context of a fox hunt. 
are included within the category of non-owned resource by reason of their temporalspatial instability. ${ }^{219}$ The 'quality of instability' produces difficulties for a system of private property because assignment to discrete individuals requires spatial and temporal stability of owned resources. ${ }^{220}$

Further material on the spatial-temporal stability of chattels is provided by the common law on water rights; specifically, groundwater and water flowing in defined channels. Groundwater is not contained within a defined channel but 'oozes through the soil in every direction in which the rain penetrates'. ${ }^{221}$ This instability precludes the existence of rights with respect to groundwater and prevents the imposition of limits upon its use. ${ }^{22}$ An owner of land containing groundwater is free to divert or appropriate it, as can their neighbor (or another person), because groundwater cannot be the 'subject of prescription or grant'. 223

A different position obtains with respect to water flowing in defined channels. ${ }^{224}$ There is no property in flowing water, but all persons who have a right to access flowing water enjoy a usufruct to the extent of reasonable use. ${ }^{225}$ Where some amount of water is abstracted from the greater flow and reduced to a person's possession, that water becomes the person's property during the time of possession. ${ }^{226}$ The imposition of stability on an otherwise unstable resource makes it amenable to private ownership.

These principles were recently recognized in the High Court of Australia's acknowledgement of the difficulties encountered when 'applying notions of ownership or property to water'. ${ }^{227}$ In its state of perpetual motion, how can water 'be isolated and tagged as the water "owned" by some person'? ${ }^{228}$ This issue has some application in the animal context because animals exhibit self-directed physical movement. ${ }^{229}$ The common law of fencing and trespass grapples with the challenges that animals pose for property's stability requirement. At common law, owners are generally not required to

219. Blackstone (n 66) 14. The common law originally recognized that an owner of land should be able to own static natural resources, but would not extend such rights to moveable resources such as water, fish and other wildlife: Bates (n 76) 70. See further Walden v Hensler (1987) 163 CLR 561.

220. See Joshua Getzler, A History of Water Rights at Common Law (Oxford University Press 2006) 43: 'riparian doctrine was shaped most immediately by an inherent feature of its subject matter: that flowing water is a thing in constant state of change ... So a running stream cannot be appropriated or possessed in the way that land as a stable, immutable object of property is capable of possession'.

221. Chasemore v Richards (1859) 7 HL Cas 349, 374 ('Chasemore').

222. ibid 369, 374-79.

223. LexisNexis, Halsbury's Laws of England (online at 22 September 2019) 100 Water and Waterways, '4 Inland Waters' [100-149]. See generally Chasemore (n 221). Note that water rights are now governed by statutory schemes in all Australian jurisdictions: LexisNexis, Halsbury's Laws of Australia (online at 22 September 2019) 440 Water, '3 Rights in Water' [440-2015].

224. See Embrey v Owen (1851) 6 Exch. 353.

225. ibid 369-70.

226. ibid 361.

227. ICM Agriculture Pty Ltd v Commonwealth (2009) 240 CLR 140.

228. ibid 190.

229. Blackstone provides an early account of this difficulty in his recognition that ferae naturae are unsuitable for private ownership and must 'unavoidably remain in common': Blackstone (n 66) 14. 
construct or maintain fencing around their land. ${ }^{230}$ However, where land is used for grazing cattle, an owner must adequately fence their property to prevent cattle from roaming. ${ }^{231}$ Animal owners are responsible for damage resulting from the trespass of their animals, ${ }^{232}$ and the payment of trespass rates and impounding fees are provided for in legislation. ${ }^{233}$ The tort of cattle trespass continues to operate on a strict liability basis, and, despite its name, extends to the trespass of any domestic animal onto the land of another. ${ }^{234}$ These rules recognize that animals are not inherently stable and require that owners impose spatial-temporal stability on their animal property.

The law on water suggests, and the law surrounding animal trespass, fencing and impoundment confirms, that imposing the requisite stability on animals involves their confinement by humans. This article adopts a notion of confinement drawn from the laws described above, viz. the imposition of stability on animals by ensuring they are kept under the owner's control. ${ }^{235}$ Such methods of confinement include fencing, caging, tethering, training, leashing and wing-clipping, among other techniques of animal husbandry. While the tagging of animals is a means of identifying the animal as owned by a particular individual, ${ }^{236}$ tagging alone does not impose the temporalspatial stability required for private ownership. Considering those animals typically tagged but subject to relatively permissive confinement (namely, cats and dogs), owners remain obliged to impose stability on their animals through the exercise of control. Legislative provisions make it an offence for dogs and cats to be 'at large' outside their owner's premises, irrespective of identification. ${ }^{237}$ Owners are liable to forfeiture of their animal property if these provisions are not complied with. ${ }^{238}$ Failure to comply amounts to a failure to confine animal property in the manner sketched above; namely, a manner that subjects the animal to its owner's control.

230. Noarlunga District Council v Coventry [1967] SASR 71; LexisNexis, Halsbury's Laws of Australia (online at 20 September 2019) 355 Real Property, '6 Other' [355-14065] ('Real Property').

231. Egerton v Harding [1975] QB 62; LexisNexis, 'Real Property' (n 230) [355-14065].

232. Doyle v Vance (1880) 6 VLR (L) 87.

233. Impounding of Livestock Act 1994 (Vic) ss 7, 16, 30, 31 and 34; Domestic Animals Act 1994 (Vic) ss $84 \mathrm{M}-84 \mathrm{~N}$ ('DAA').

234. Davis v Cole [1939] VLR 320. Animal owners can also be liable for losses flowing from their unfenced animals through the doctrine of scienter and the tort of negligence. See generally LexisNexis, Halsbury's Laws of Australia (online at 20 September 2019) 20 Animals, '5 Liability of Owners and Keepers of Animals' for a precise compendium of the relevant law.

235. Note however that a designated literature concerning the notion of animal confinement exists. See, for example, Robert Strieffer and David Killoren, 'Animal Confinement and Use' (2019) 49(1) Canadian Journal of Philosophy 1, where a conception of agential confinement is advanced as an accurate understanding of animal confinement.

236. Microchipping of both cats and dogs is mandatory in many Australian jurisdictions: see, for example, DAA (n 233) s 10C; Companion Animals Act 1998 (NSW) s 8.

237. DAA (n 233) ss 24-25. Note that the prohibition in s 25 regarding cats is given content by local council rules. Cats must be confined and controlled by their owner to the extent required by these rules, which may, for example, impose a curfew requiring cats to be on the owner's property at specified times.

238. Animals can be seized and impounded if these provisions are not complied with: ibid ss 84 and $84 \mathrm{D}$. No limitation to unidentified animals is found in these sections, in contrast to $\mathrm{s}$ 84A. While identification reduces the likelihood of impoundment by providing a means to readily locate the owner, it does not replace the requirement of control, re-established when the owner collects their animal and reasserts their right of possession. Failure to collect an animal will result in its impoundment and the loss of property rights. Possession can only be regained if 
Whether confinement is strict and physical (for example, a frog in a tank) or expansive and imposed through conditioning or training (a cat that returns to its owner's property in the evening, for example) temporal-spatial stability must be imposed upon animals to render them the sorts of objects that possess the characteristics required of chattels. This is achieved through confinement (physical or otherwise). The next section considers whether the confinement of animals conflicts with the non-deterioration thesis. Strong arguments suggest that contemporary forms of confinement for the vast majority of animal property cause the deterioration of society's resources. If these arguments are accepted as persuasive, the existence of animal property undermines external wellbeing theories and brings normative incoherence to the private property institution.

\subsubsection{The Role of Confinement in Deterioration}

The confinement of animals makes a significant contribution to the deterioration of valuable resources. This was not the case in all contexts throughout history. ${ }^{239}$ Prior to large-scale industrialization, harnessing horses to plough fields and raising other animals for meat, milk and eggs made greater resources available to the community. Nevertheless, the scales at which animal property is presently kept and confined violate the non-deterioration thesis. The system of incentives generated by private ownership secures preservation of and production from the individual resource, but the consequentialist focus of external wellbeing theories directs attention to the aggregate outcomes of the private property system. ${ }^{240}$ Animal property exists and is used in a great number of contexts; but again, the focus on outcome directs our attention to the primary use of animal property: food. ${ }^{241}$ The fundamental consequentialism of external wellbeing theories means this article does not (and does not seek to) establish that animal property could not conceivably serve external wellbeing theories. Instead, the analysis of external wellbeing theories considers the contemporary outcomes that animal property (and confinement) present for resource use and availability in a particular context: present-day liberal economies.

\subsubsection{Livestock and Deterioration}

The confinement of livestock in contemporary economies is primarily intensive, but some is extensive or 'free range'. ${ }^{242}$ Intensive confinement systems cause deterioration

a fee is paid within a stipulated time and, again, control is re-established: see ss $84 \mathrm{M}$ and $84 \mathrm{~N}$. If the animal is not reclaimed within a stipulated time, property in the animal transfers to the entity that is exercising control: s 840 .

239. Utilitarian property theories are well-recognized as "potentially extremely sensitive to context': Alexander and Peñalver (n 13) 29.

240. Similarly, utilitarian theories involve aggregation of the relevant social good or utility: ibid 12-14.

241. Singer (n 10) 95.

242. Accurate statistics on the numbers of animals raised in intensive livestock production systems (factory farms) are difficult to ascertain, but the numbers are high and continue to rise. The Sentience Institute estimates that 99 percent of animals raised for food in the United States are factory farmed in intensive systems: Jacy Anthis, 'US Factory Farming Estimates', Sentience Institute (Web Page, 17 November 2020) <www.sentienceinstitute.org/us-factory-farming-estimates $>$. Globally, around two-thirds of animals raised for meat are factory farmed. In 2006, 45 percent 
of the animals involved, but simultaneously produce large volumes of animal product at low cost to the consumer. ${ }^{243}$ Deterioration of the living animal can be readily appreciated through consideration of the life of a broiler chicken. ${ }^{244}$ Broiler chickens, raised for meat, are housed in large sheds at densities of 20 birds per square meter. ${ }^{245}$ Such high stocking densities render the birds virtually immobile and lead to increased rates of mortality, breast blisters, leg disorders, chronic dermatitis, reduced socialization and expression of other natural behaviors, and disturbed resting patterns. ${ }^{246}$ Infection and disease are rife in intensive systems, and require the industry-wide use of antibiotics to curb their effects. ${ }^{247}$ With reference to physiological, behavioral and physical indicators, intensively farmed chickens clearly deteriorate.

However, as noted above, external wellbeing theories direct attention to preservation and cultivation of the individual resource with a view to maximizing the resources available to society. A net increase in society's available resources that relies on the deterioration of animal property would therefore serve external wellbeing theories. However, the apparent contribution of animal products to society's available resources is deceiving because it is undercut by externalities. The private property system has been identified as a means to internalize external costs (for example, those borne by 'neighbours and subsequent generations') by allocating to the individual owner the 'full costs' of their activities. ${ }^{248}$ This does not occur in the animal context. The immediate availability of animal product masks the direct and indirect destruction of other resources that flow from animal confinement; specifically, the confinement of animals (livestock) for the purpose of food production.

of animals were raised in intensive landless systems. 46 percent were raised in mixed systems, which accommodate intensive farming. Only 8 percent were raised in grazing systems: Food and Agriculture Organisation of the United Nations ('FAO'), Livestock's Long Shadow Environmental Issues and Options (Report, 2006) 45 ('Livestock's Long Shadow').

243. Ruth Harrison, Animal Machines (CABI Publishing 1964, 2013 reprint) 35.

244. The practice of chicken farming is used for numeric reasons. Excluding wild-caught fish, chickens are raised and slaughtered for food in vastly greater numbers than any other land animal. In Australia in 2020/2021, 666.5 million chickens were slaughtered for meat, and most are intensively farmed: Australian Bureau of Statistics, 'Livestock Products, Australia', Agriculture (Web Page, 8 August 2021) <www.abs.gov.au/statistics/industry/agriculture/livestock-productsaustralia/latest-release>.

245. Space allowances vary based on the weight of the chicken and the jurisdiction in which it is located. The figure of 20 birds per square meter is based on the Primary Industries Standing Committee, Model Code of Practice for the Welfare of Animals: Domestic Poultry, (4th edition) (2002) paragraphs 2-3 and Appendix 2. This Code will soon be replaced with an updated Australian Animal Welfare Standards and Guidelines for Poultry pursuant to a government initiative that aims to create nationally consistent standards and guidelines for farm animal welfare.

246. Voiceless, How are chickens raised for meat in Australia? (Fact Sheet, June 2017) 4, 11-12. Several studies have empirically shown that animal product quality deteriorates in intensive modes of confinement: see Siyu Chen et al, 'Free Dietary Choice and Free-Range Rearing Improve the Product Quality, Gait Score, and Microbial Richness of Chickens' (2018) 8 Animals 84; Cheng Yung Lin, Hsiao Yun Kuo and Tien Chun Wan, 'Effect of Free-Range Rearing on Meat Consumption, Physical Properties and Sensory Evaluation in Taiwan Game Hens' (2014) 27(6) Asian-Australian Journal of Animal Science 880.

247. Youcef Mehdi et al, 'Use of Antibiotics in Broiler Production: Global Impacts and Alternatives' (2018) 4(2) Animal Nutrition 170.

248. Demsetz (n 197) 347, 354-58. 
Our understanding and appreciation of these externalized costs is nonetheless growing. 249

The United Nations has identified the livestock sector as 'one of the two or three most significant contributors to the most serious environmental problems, at every scale from local to global'. ${ }^{250}$ These problems entail the deterioration of society's natural resources. The livestock sector is a leading driver of land degradation, habitat destruction, deforestation, pollution of air, water and surfaces, climate change and biodiversity loss. ${ }^{251}$ Livestock production systems also make significant contributions to the depletion of water resources, acidification and eutrophication. ${ }^{252}$ They are 'by far the largest anthropogenic user of land', occupying 30 percent of the ice-free terrestrial surface of the planet. ${ }^{253}$ The expansion of livestock production is a 'key factor' in deforestation, particularly in valuable tropical forest areas. ${ }^{254}$

The livestock sector is responsible for 18 percent of anthropogenic greenhouse gas emissions and over eight percent of global human water use. ${ }^{255}$ It is the largest sectoral source of water pollution, contributing to eutrophication, dead zones in coastal areas and the degradation of coral reefs. ${ }^{256}$ The trends towards intensification are increasing both inputs and waste products, which in turn increases and concentrates the pollution created. ${ }^{257}$ The scale and severity of these issues cannot be understated and deserve much greater analysis than can be presented here. ${ }^{258}$

The environmental consequences sketched above are instances of the deterioration of natural resources. The confinement of livestock also leads to depletion of other resources. The mass use of antibiotics for livestock makes a significant contribution to antibiotic

249. Some food scientists dispute the environmental cost of intensive livestock systems, making this observation particularly pertinent. Intensive systems produce more animal product with reduced resource input through the 'dilution of maintenance' effect: improved productivity will reduce the total maintenance cost per unit of food, because fewer animals are needed to produce a set quantity of animal product: see JL Clapper, 'The Environmental Sustainability of Food Production' in E Kebreab (ed), Sustainable Animal Agriculture (CABI Publishing 2014) 157,158 . Nevertheless, the 'dilution of maintenance' effect does not negate the externalized costs of large-scale intensive (and extensive) livestock production systems.

250. FAO, Livestock's Long Shadow (n 242) xx.

251. ibid xxiii.

252. See also J Poore and T Nemecek, 'Reducing Food's Environmental Impacts through Producers and Consumers' (2018) 360 Science 987.

253. FAO, Livestock's Long Shadow (n 242) xxi, 271-72.

254. ibid.

255. ibid xxii, 112, 272. This is a conservative estimate of the livestock sector's contribution to anthropogenic greenhouse gas emissions. The Worldwatch Institute's Livestock and Climate Change report, released three years after the FAO's report in 2009, claims that animal agriculture is responsible for at least 51 percent of annual greenhouse gas emissions. The larger figure accounts for the earth's decline in photosynthetic capacity caused by livestock production and concomitant deforestation and forest burning. For further explanation of the debate, see Jonathan Safran Foer, We are the Weather: Saving the Planet Begins at Breakfast (Farrar, Straus and Giroux 2019) 227-32.

256. FAO, Livestock's Long Shadow (n 242) xxii.

257. ibid xxi.

258. Indeed, these observations may also produce some tension for other objects of property, such as the products of logging and mining industries. Whether this tension has force will depend on the content and extent of resource deterioration produced by these products. These issues are beyond the scope of this article. In any event, it seems unlikely that objects produced through logging or mining present issues for internal wellbeing property theories. 
resistance and depletes the utility of these life-saving compounds. ${ }^{259}$ Livestock products are more susceptible to pathogens than other food products, presenting issues for human health and food safety. ${ }^{260}$ For example, campylobacter contamination of chicken in the United Kingdom makes hundreds of thousands of people sick and kills approximately 100 people each year. The attendant effects on societal resources are approximated by the cost of contamination to the UK economy: $£ 900$ million each year. ${ }^{261}$

The role played by livestock and their confinement in the emergence of zoonotic disease is also significant. Livestock production is a principal driver of zoonotic disease. In a recent report produced in response to the COVID-19 global pandemic, the United Nations identified increasing human demand for animal protein, unsustainable agriculture intensification, increased use and exploitation of wildlife and climate change as four of seven human-mediated factors most likely to drive the emergence of zoonotic disease. ${ }^{262}$ Zoonotic disease has severe and dramatic effects on resource production, preservation and destruction, as reflected in its untold economic consequences. $^{263}$

In response to the claim that animal confinement violates the non-deterioration thesis, one may assert that confinement is a matter of degree. Confinement in non-industrial contexts is not readily associated with the resource destruction sketched above. Nevertheless, the mere existence of non-industrial animal confinement does not offset the externalized costs that flow from the confinement of animals in industrial settings. ${ }^{264}$ Livestock confinement leads to significant deterioration of resources and its quantitative dominance strongly bears upon the outcomes produced by animal property within the private property system. It is these outcomes to which external wellbeing theories appeal for their justification of private property. Indeed, serious questions surround whether livestock production systems can produce better environmental outcomes whilst feeding the growing population. ${ }^{265}$

Aggregating and balancing the outcomes of production and deterioration that flow from animal property is a complex task. ${ }^{266}$ Nonetheless, the numerical dominance of

259. Mehdi et al (n 247).

260. FAO, Livestock's Long Shadow (n 242) 269.

261. Felicity Lawrence, 'Food Poisoning Scandal: How Chicken Spreads Campylobacter', The Guardian (United Kingdom, 24 July 2014).

262. United Nations Environment Programme, Preventing the next pandemic: zoonotic disease and how to break the chain of transmission (Report, 2020) 7, 15-17. See also Bryony Jones, 'Zoonosis Emergence Linked to Agricultural Intensification and Environmental Change' (2013) 110 Proceedings of the National Academy of Sciences 8399.

263. See, for example, the economic impact of COVID-19: Eduardo Levy Yeyati and Federico Filippini, Social and economic impact of COVID-19 (Brookings Global Working Paper \#158, June 2021), particularly at 1,4 .

264. See Katherine Groff et al, 'Review of Evidence of Environmental Impacts of Animal Researching and Testing' (2014) 1 Environments 14, regarding the environmental costs of animal use and confinement for scientific testing and research, another major animal use industry.

265. Poore and Nemecek (n 252) state that 'dietary change can deliver environmental benefits on a scale not achievable by producers', describing the move from current to plant-based diets as having 'transformative potential': at 991 . Such a shift would reduce food land use by 76 percent, food greenhouse gas emissions by 49 percent, acidification by 50 percent and eutrophication by 49 percent in a given year. These statistics have led to identification of a plant-based diet as the route to long-term food security: see M Berners-Lee et al, 'Current Global Food Production is Sufficient to Meet Human Nutritional Needs in 2050 Provided There is Radical Societal Adaptation' (2018) 6(1) Elementa Science of the Anthropocene 52.

266. Alexander and Peñalver (n 13) 13-14. 
livestock confinement and the severity of its concomitant costs provide a strong indication that resource deterioration is the net outcome. ${ }^{267}$ External wellbeing theories require, as a practical matter, that objects of property have certain characteristics (namely, temporal-spatial stability), but are otherwise unconcerned with the intrinsic nature of chattels. As such, external wellbeing theories cannot be used to mount an argument that animals are an inherently unsuitable object of property rights. Rather, these theories can be used to critique the suitability of property status in particular contexts: here, contemporary liberal economies. Animal welfare laws and associated regulatory instruments could conceivably be drafted to prescribe confinement regimes that do not violate the non-deterioration thesis. Such a change would require radical reform of present industrial and consumer practices, particularly because deterioration seems a necessary corollary of the scale of present demand. Nonetheless, the extremity of reform does not undermine its ability to dramatically reduce, if not remove, the tensions produced by animal confinement for external wellbeing theories.

Moving away from the major industrial use of animals as food, the confinement of animals in other industries may not undermine the non-deterioration thesis. This statement largely depends upon the scale at which animals are kept. The confinement of pets, for example, is unlikely to present concerns for the deterioration of societal resources. Nevertheless, reasons of institutional design indicate that the search for a suitable classification for animals must operate at a level of relative generality. As Rawls has recognized, an institution's overarching goal (for example, maximizing society's available and productive resources) is best achieved through the application of bright-line, workable rules. ${ }^{268}$ The line must be drawn somewhere. Presently, the classification of animals as property extends to all domestic animals, with the distinction between domestic and wild animals being a question of law, drawn at the species level. Yet animals of the same species are often implicated in the different contexts contemplated by this article: dogs are beloved pets but also used as laboratory animals; rabbits are similarly family pets but also used in meat farms and laboratories. Even cows, typically used for milk and meat production, are also found in non-industrial contexts such as hobby farms. Reasons of institutional design proscribe the assessment of animals' legal classification at a level more specific than its species. Legal classifications must be sufficiently expansive to be insensitive to these differences of context. It is clearly impracticable to assess an animal's legal classification as dependent upon a factual inquiry concerning the actual contribution to resource deterioration made by their individual regime of confinement. Considering the net outcomes that flow from animal confinement and the tensions raised by animal property for internal wellbeing theories, nonhuman vertebrate animals are, as a group, an unsuitable object of property rights.

\section{FUTURE STEPS}

This article has considered the challenges that the classification of animals as property presents for traditional property theories and concluded that, by reference to those theories, animals are an unsuitable object of property rights. This is not the end of the

267. Note that animal use in other contexts not accompanied by such damning externalized costs (such as animals used as pets and in entertainment industries) are not readily understood as making greater resources available for society in the same way as animals used for food. 268. See Rawls, Two Concepts (n 101). 
inquiry. Since property proves a doctrinally unsatisfactory solution, what category would provide a suitable classification? A legal category for animals must accommodate certain practical matters that arise with respect to animals that coexist with humans and form part of our societies. The allocation of responsibility and decisional authority with respect to those animals are important concerns. These matters were readily provided for by property law and made property a superficially attractive classification. But we do not need the concept of property to resolve them. An appropriate legal classification for animals should be sensitive to those characteristics that cause tension for internal wellbeing theories; namely, animal sentience and their capacity for self-directed, purposive behaviors. Some alternative frameworks for a classification for animals, sensitive to these characteristics, have already been developed. By analyzing the doctrinal problems presented by property status, this article propels these approaches further.

Personhood theories are an important class of alternative frameworks. Primary amongst these approaches is the work of Steven Wise. Wise advocates for the legal personhood of certain primates, elephants and cetaceans as a necessary precondition to recognition of their rights to bodily liberty and integrity. ${ }^{269} \mathrm{He}$ produces comprehensive evidence of their cognitive and emotional capacities and appeals to western law's values of equality and liberty as a basis on which to attack the arbitrary denial of rights from those entitled to hold them. Wise's consideration of the common law leads him to identify individual autonomy as a sufficient basis for recognition of legal personhood. ${ }^{270}$ The arguments presented in this article complement Wise's approach because they demonstrate that animals must be removed from the property paradigm; Wise then makes the positive argument that personhood is an appropriate place for their classification to rest.

Other frameworks are advanced by this article. Will Kymlicka and Sue Donaldson's political theory of animal rights moves beyond considerations of the intrinsic worth of animals and advocates that domestic animals are deserving of citizenship status. ${ }^{271}$ This theory is strengthened through demonstrating the deficiency of a classification that ignores the considerations it responds to. ${ }^{272}$ Even approaches that do not fully disrupt the property paradigm, such as David Favre's arguments for equitable selfownership, ${ }^{273}$ are advanced by the conclusion that animals' present classification is unsatisfactory. Indeed, all approaches that seek a different classification for animals are assisted by the conclusion that animal property brings incoherence to the private property system.

\section{CONCLUSION}

Our intuitive discomfort surrounding animals' classification as property is reflected in legal theory. While the property paradigm has defined human-animal interaction for thousands of years, this does not justify the existence of a property form that does not serve, and even undermines, the institution's overarching goals. This article has raised

269. See Wise, Rattling the Cage (n 6).

270. See ibid.

271. Kymlicka and Donaldson (n 11) 201.

272. Humans have brought domesticated animals into their societies and absorbed them within schemes of cooperation and dependency: see ibid, particularly at 204.

273. See Favre (n 11). 
reasons of legal theory that expose the doctrinal deficiencies of animals' property status. While not resolving the ultimate question of a suitable legal classification for animals, this conclusion advances a number of approaches for animal protection by establishing a fundamental preliminary premise: the present classification of animals as chattels is untenable. The task now turns to the determination of a proper legal status for nonhuman animals, enabling the law to move beyond incoherence and towards a meaningful framework for animal protection. 